\title{
AVALIAÇÃO DA VIABILIDADE JURÍDICA DE UM INSTRUMENTO INTERNACIONAL SOBRE A DIVERSIDADE CULTURAL ${ }^{1}$
}

\author{
Ivan Bernier*
}

Hélène Ruiz Fabri*

\section{Parte I. Os textos existentes no plano internacional capazes de regulamentar o comércio de bens e serviços culturais}

O presente apanhado sobre os instrumentos multilaterais, regionais ou bilaterais capazes de regulamentar de alguma maneira o comércio dos produtos culturais não pretende ser exaustiva, contudo, ela fornece uma idéia bastante satisfatória da multiplicidade e da diversidade dos instrumentos em questão ${ }^{2}$

O conceito de instrumento internacional subjacente se refere a uma gama extremamente variada de textos internacionais, indo da simples recomendação até aos acordos internacionais de caráter obrigatório, passando pelas resoluções, declarações, decisões e por cartas e planos de ação.

A sua característica comum reside na sua origem de norma internacional, o que exclui, entre outros, os textos que provêm de organizações não-normativas.

\footnotetext{
${ }^{1} \mathrm{O}$ presente documento se refere a uma consulta feita Grupo de trabalho franco-quebequiano sobre a diversidade cultural a dois professores especialistas em direito internacional econômico. Ele busca responder a três perguntas específias que refletem o estado da arte na teoria internacional sobre este importante tema. Todos os direitos reservados. Depósito legal: segundo trimestre, 2002 de Biblioteca Nacional do Québec ISBN - 2-55039185-3

* Professor associado da Faculdade de Direito da Universidade Laval do Quebeque

* Professora da Universidade de Paris I - Panthéon-Sorbonne

${ }^{2}$ Este apanhado esta baseado nos seguintes ducumentos: BERNIER, Ivan et Jean-François LAMOUREUX. «Les politiques culturelles du Canada et du Québec, l'Organisation mondiale du commerce (OMC) et l'Accord de libre-échange nord américain (ALENA) », dans Les politiques culturelles à l'épreuve - La culture entre l'État et le marché, sous la direction de Florian Sauvageau, Québec, Institut québécois de recherche sur la culture, 1996, pp 1-69; BERNIER, Ivan. «Cultural Goods and Services in International Trade Law» dans The Culture/Trade Quandary - Canada’s Policy Options, Dennis Browne éd., Centre for Trade Policy and Law, Ottawa, 1998, pp. 108-148; BERNIER, Ivan. Catalogue des instruments internationaux relatifs à la culture, 2 000: disponible sur le site http://www.mcc. gouv.qc.ca/international/diversite-culturelle/index.htm ; PAAPE, S. Treatment of Culture in Trade and Economic Agreements, monographie, avril 2000 ; SAUVÉ, Pierre. Le traitement des produits et services culturels dans les accords commerciaux, Agence de la Francophonie, 2000
} 


\section{Os acordos multilaterais}

\subsection{O regime jurídico da OMC}

\subsubsection{O Acordo Geral sobre Tarifas e Comércio (GATT)}

As preocupações da OMC em relação à cultura e aos produtos culturais não são recentes. No texto original do Acordo geral sobre tarifas e comércio adotado em 1947, já se encontra um dispositivo, o artigo IV, que mostra bem até que ponto os fundadores do sistema comercial multilateral eram sensíveis nessa época ao perigo que pode representar para as culturas nacionais uma prática sem nuances do princípio da livre circulação das mercadorias.

O artigo IV estipula que uma Parte Contratante pode manter uma regulamentação quantitativa interna que comporta a obrigação de projetar, por um determinado período, filmes de origem nacional durante uma fração mínima do tempo total de projeção efetivamente utilizado.

Dito isto, o artigo IV estipula que as cotas de projeção deverão ser objeto de negociações que tendem a limitar o seu alcance, abrandá-lo ou suprimi-lo. O artigo IV do GATT 1947 (que foi reconduzido ao término da Rodada Uruguai no GATT de 1994) diz que:

Se uma parte contratante estabelecer ou mantiver regulamentações quantitativas internas relativas aos filmes cinematográficos expostos, tais regulamentações deverão ser impostas sob a forma de cotas de projeção, que obedecerão às condições e prescrições seguintes: a) As cotas de projeção poderão tornar obrigatória a exibição de filmes cinematográficos de origem nacional durante uma proporção mínima determinada do tempo total de projeção, realmente utilizado num período não inferior a um ano na exibição comercial de todos os filmes de qualquer origem; e serão computados na base do tempo de projeção anual por sala ou de seu eqüivalente.

O dispositivo em questão foi inserido porque tais regulamentações restritivas eram percebidas com o objetivo de "priorizar mais as políticas culturais nacionais do que a

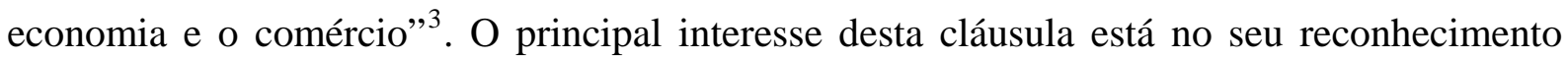
explícito da especificidade do filme como um produto que entra no comércio internacional.

Além do artigo IV, o único outro dispositivo do GATT de 1994 que se refere diretamente ao comércio dos bens culturais se encontra ao artigo XX(f), que reconhece como

\footnotetext{
3 JACKSON, John H. World Trade and the Law of GATT, Indianapolis, Kansas City, New York, The Bobbs Merrill Co. Inc., 1969, p. 293.
} 
exceção as restrições impostas para a proteção de tesouros nacionais que tenham um valor artístico, histórico ou arqueológico. Este artigo declina-se da seguinte maneira:

Desde que essas medidas não sejam aplicadas de forma a constituir quer um meio de discriminação arbitrária, ou injustificada, entre os países onde existem as mesmas condições, quer uma restrição disfarçada ao comércio internacional, disposição alguma do presente capítulo será interpretada como impedindo a adoção ou aplicação, por qualquer Parte Contratante, das medidas:

f) impostas para a proteção de tesouros nacionais de valor artístico, histórico ou arqueológico;

Fora estas duas exceções, os produtos culturais devem, do ponto de vista do sistema de regras multilaterais que regulam o comércio, ser tratados exatamente como qualquer outro produto comercial. Isto é precisamente o que sugere a recente decisão do Órgão de Solução de Controvérsias da OMC no caso Canadá - Certas medidas relativas aos periódicos ${ }^{4}$ onde dispositivos destinados a proteger a indústria canadense dos periódicos foram julgados incompatíveis com os artigos III (tratamento nacional) e XI (restrições quantitativas) do GATT de 1994. Nós veremos mais adiante o impacto potencial desta decisão sobre as intervenções nacionais no domínio cultural.

\subsubsection{O Acordo geral sobre o comércio dos serviços (GATS)}

Diferentemente do GATT de 1994, e embora tenha sido o principal espaço de confrontação entre o comércio e a cultura (principalmente no setor audiovisual) quando da Rodada Uruguai, o GATS não comporta cláusula específica relativa à cultura ou aos produtos culturais. No entanto, os serviços culturais beneficiam de certas dispositivos que permitem a manutenção de medidas nacionais que seriam incompatíveis com o compromisso inicial das partes de conceder o tratamento da nação mais favorecida, ou permitem a manutenção, em setores onde nenhum compromisso específico de liberalização foi ainda tomado, de medidas incompatíveis com o princípio do tratamento nacional ou que venham limitar o acesso ao mercado interno.

O principal compromisso das partes signatárias do GATS encontra-se no artigo II,

\footnotetext{
${ }^{4} \mathrm{OMC}$, Doc. WT/DS31/AB/R. 
parágrafo 1, que prescreve que, no que diz respeito a todas as medidas cobertas pelo Acordo, “cada Parte atribuirá, de forma imediata e incondicional, aos serviços e fornecedores de serviços de qualquer outra Parte, um tratamento não menos favorável que aquele que atribui aos serviços similares e aos fornecedores de serviços similares de qualquer outro país”. O artigo II:1 do GATS é de aplicação geral, e diz respeito a toda parte do Acordo, não importando que tenha ou não subscrito compromissos de liberalização no setor. No entanto, nos termos do parágrafo 2 deste mesmo artigo, “um Membro poderá manter uma medida incompatível com o parágrafo 1 desde que esta figure no Anexo sobre as isenções das obrigações enunciadas no artigo II e satisfaça às condições que são indicadas no referido anexo”. As condições em questão prevêem que todas as isenções atribuídas por um período de mais de cinco anos devem ser objeto de um reexame e que em princípio, as exceções não deveriam exceder um período de dez anos. Na prática, não menos que 27 Estados, dos quais vários países latino-americanos, nórdicos, europeus e árabes, assim como o Canadá, pediram que as convenções de co-produção e co-distribuição das obras cinematográficas e televisivas figurem no anexo sobre as isenções das obrigações enunciadas no artigo II por razões vinculadas essencialmente à conservação de identidades nacionais e regionais ${ }^{5}$.

Entre os dispositivos mais importantes do GATS, encontram-se aqueles que se referem a acesso ao mercado e ao tratamento nacional, que se encontram na parte III do Acordo e tratam dos compromissos específicos dos membros. De acordo com o esquema originalmente desenvolvido no Acordo do GATT de 1947 para o comércio dos bens, o novo acordo sobre os serviços prevê que além dos compromissos gerais incorporados às partes I e II, as partes signatárias deverão assumir compromissos específicos relativos à liberalização das trocas de serviços em setores da sua escolha em resposta a pedido das outras Partes

\footnotetext{
5 Os acordos regionais e bilaterais de co-produção e co-distribuição são numerosos e envolvem países de todas as regiões do mundo (Ásia, Oriente-Médio, África, Europa, América do Norte e América Latina). Estes cordos, sendo por definição contários ao tratamento da nação mais favorecida, não pode ser mantidos pelos países membros da OMC, na medida em que eles são mencionados no anexo relativo às isenções ao artigo II do Acordo Geral sobre Comércio de Serviços. A leitura deste anexo é particularmente interessante, porque ela incorpora uma coluna na qual os Estados relacionados fornecem explicação sobre a razão de ser da sua insenção. Em praticamente todos os casos, a isenção em questão é justificada pela necessidade de manter a preservação e a promoção de uma identidade nacional ou regional. As isenções ao artigo II do GATS valem apenas para as medidas em vigor à partir de 1o de janeiro de 1995 e não deveria, em princípio, ultrapassar um período de 10 anos. Na prática, novos acordos de co-produção são regularmente concluidos e é mais do que duvidoso que aqueles atualmente protegidos pelo Anexo desapareçam em 2005. Dito isso, um revisão das isenções ao artigo II e das discussões sobre a oportunidade de eliminá-los ou de reduzir progressivamente a incidência sobre o comércio está inscrita no programa de trabalho atual do AGCS.
} 
Contratantes. Os principais compromissos que aceitam, inscrevendo voluntariamente (ou seja, de maneira "positiva”) uma dada categoria de serviços na sua lista, refere-se ao acesso ao mercado e a concessão do tratamento nacional, assuntos nos dois casos com exceções claramente explícitas na lista em questão.

Nos termos do parágrafo 1 do Artigo XVI do GATS tocante ao acesso a mercados, “cada Membro atribuirá aos serviços e aos fornecedores de serviços de qualquer outro Membro um tratamento que não será menos favorável que o que está previsto em conformidade com as modalidades, limitações e condições acordadas e especificadas na sua Lista”. Na prática, poucos Estados assumiram tal compromisso no setor cultural (13 dos 105 signatários do acordo de Marrakech e 19 dos 142 membros atuais da OMC), e alguns que o fizeram incluíram diversos tipos de limitações aos seus compromissos. ${ }^{6}$

As partes signatárias aceitam igualmente, nos termos do artigo XIX, participar de séries sucessivas de negociações a fim de elevar progressivamente o nível de liberalização, a primeira devendo começar, no mais tardar, cinco anos após a entrada em vigor do Acordo na OMC. Estas negociações retomaram em primeiro Janeiro de 2000 a título da ordem do dia preestabelecida vinda da Rodada Uruguai . A retomada das discussões já permitiu aos Estados Unidos apresentar a sua firme intenção de ver os membros do GATS melhorar o teor qualitativo (e às vezes quantitativo) dos seus compromissos de liberalização em matéria de indústrias culturais sob o GATS . é importante, contudo, recordar que o GATS opera com base numa abordagem dita por "lista positiva" em se tratando da sua mecânica de liberalização.

Feito isto, os Estados membros da OMC continuarão durante as próximas rodadas de negociações a gozar de uma total discricionariedade na matéria. Nada obriga, na prática, a que seja concedida qualquer concessão em matéria cultural

Do mesmo modo, dado que os produtos culturais estão cobertos pela disciplina do GATS, as discussões atuais sobre subvenções, regulamentação interna e medidas de salvaguarda (no caso de prejuízo não previsto às indústrias nacionais decorrente da abertura dos mercados à concorrência estrangeira) em matéria de comércio de serviços, interessarão

\footnotetext{
${ }^{6}$ E neste contexto preciso que é preciso sitauar a demanda de autoria dos Estados Unidos para as Comunidades européias para elimiar as cotas audiovisuais pela diretiva « Televisão sem fronteiras », pedido o qual esta deve eventualmente recusar seu aceite.
} 
diretamente ao tratamento futuro das indústrias culturais no âmbito (ou fora) da OMC. Será necessário, então, que estas negociações levem em conta os efeitos possíveis desse tipo de regulamentação sobre a formulação das políticas culturais nacionais. Se progressos tangíveis sobre a questão das salvaguardas foram registrados recentemente, acreditando na idéia de que esse tipo de regulamentação possa eventualmente ser incorporado ao GATS, as discussões sobre regimes de subvenções e a sua incidência sobre o comércio dos serviços até agora não têm produzido resultados importantes.

\subsubsection{O Acordo sobre os aspectos do direito de propriedade intelectual que tocam ao comércio} (TRIPS)

A proteção dos direitos de autor e os direitos conexos é de uma importância capital como apoio à criação artística. A propósito, não é surpresa constatar que o direito de autor seja mencionado expressamente como um direito da pessoa humana na Declaração universal dos direitos do homem, no Pacto internacional relativo aos direitos econômicos, sociais e culturais, bem como na Declaração americana dos direitos e deveres da pessoa humana.

A importância crescente do comércio dos produtos culturais, como o livro, os registros sonoros, o conteúdo televisivo e cinematográfico, mostra também o lugar central que estas perguntas devem ocupar nos sistemas comerciais multilaterais. O Acordo sobre o TRIPS, que como todos os acordos oriundos da Rodada Uruguai entrou em vigor 1 Janeiro de 1995, é até agora acordo multilateral mais completo em matéria de propriedade intelectual em termos de comércio. O Acordo articula-se entorno de três elementos principais:

(i) Normas. O Acordo sobre os TRIPS estabelece, para cada um dos principais setores da propriedade intelectual que ele aborda, as normas mínimas de proteção que devem ser previstas pelos membros. Os principais elementos da proteção são definidos, a saber, o objeto da proteção, os direitos conferidos e as exceções admitidas a estes direitos, assim como a duração mínima da proteção. O Acordo estabelece estas normas exigindo em primeiro lugar que as obrigações de fundo enunciadas nas versões mais recentes das principais convenções da OMPI, a Convenção de Paris para a proteção da propriedade industrial (Convenção de Paris) e a Convenção de Berna para a proteção de obras literárias e artísticas (Convenção de Berna), sejam respeitadas. Com exceção das dispositivos da Convenção de Berna relativas aos 
direitos morais, todas os principais dispositivos de fundo destas convenções são incorporadas por referência e se tornam assim, no âmbito do Acordo sobre os TRIPS, obrigações para os Estados membros que participam do Acordo. Em segundo lugar, o Acordo sobre os TRIPS introduz um número importante de obrigações suplementares nos domínios onde as convenções preexistentes inexistem ou são julgadas insuficientes. Fala-se assim às vezes do Acordo como um acordo que reforça as Convenções de Berna e de Paris.

(ii) Meios para fazer respeitar os direitos. O segundo grande conjunto de dispositivos refere-se aos procedimentos e medidas corretivas internas destinadas a fazer respeitar os direitos de propriedade intelectual. O Acordo enuncia certos princípios gerais aplicáveis a todos os procedimentos deste tipo. Ele contém, além disso, dispositivos referentes aos procedimentos e medidas corretivas cíveis e administrativas, medidas cautelares, prescrições especiais relativas às medidas na fronteira e procedimentos penais, que indicam, de maneira bastante detalhada, os procedimentos e medidas corretivas que devem estar previstas para permitir aos que detêm os direitos de fazer respeitá-los de maneira efetiva.

(iii) Solução de controvérsias. Em virtude do Acordo sobre os TRIPS, a controvérsias entre membros da OMC relativos ao respeito das obrigações que decorrem do Acordo são tratados no âmbito dos procedimentos de solução de controvérsias da OMC.

Além do interesse especial que representa no domínio da criação artística a melhor aplicação do TRIPS pelos membros da OMC, a próxima rodada de negociações poderia ser a oportuna para incorporar os pontos negociados em 1996 na Organização Mundial da Propriedade Intelectual (OMPI) sobre a proteção do direito de autor na sociedade da informação. Uma atenção particular deverá igualmente ser prestada às incidências possíveis do programa de trabalho da OMC em matéria de comércio eletrônico para as políticas de apoio às indústrias culturais e proteção dos conteúdos culturais e os seus inventores. Embora a idéia possa parecer intuitivamente sedutora tendo em conta o dinamismo tecnológico do setor e a convergência em curso entre o setor das telecomunicações e a produção audiovisual, não é de forma alguma evidente no estado atual da reflexão que uma abordagem fundada sobre “a abstinência regulamentaria” em matéria de comércio eletrônico seja necessariamente compatível com a idéia de promover a diversidade cultural.

\subsection{A cooperação internacional fora da OMC}


1.2.1 Facilitação do comércio de produtos educativos, científicos e culturais.

Reconhecendo que a livre circulação dos produtos (entendido aqui como o comércio das mercadorias) de caráter educativo, científico e cultural constitui um bem público internacional de certa forma, a comunidade internacional concluiu alguns acordos destinados a facilitar o comércio e a divulgação de tais produtos. Vários destes foram concluídos na onda da fundação do GATT, sem, contudo ter o mesmo caráter juridicamente regulatório. É o caso, principalmente, de dois instrumentos negociados sob a égide da UNESCO:

- Acordo visando facilitar a circulação internacional de material visual e auditivo de caráter educativo, científico e cultural, concluído sob a égide da UNESCO em Beirute em 1948. Trata-se essencialmente de um acordo aduaneiro que visa a supressão dos entraves tarifários sobre as seguintes categorias de materiais: filmes, filmes fixos, microfilmes, registros de som, diapositivos, maquetes e modelos mecânicos, quadros murais, mapas e cartazes).

- Acordo para a importação de objetos de caráter educativo, científico e cultural, estabelecido em Florença em 1950, que visa suprimir as pautas aduaneiras e outros obstáculos que obstruam as trocas não apenas de material visual e auditivo, mas também de várias outras categorias de matérias. Um Protocolo ao Acordo de Florença foi adotado em Nairobi em 1976. Este último estende a isenção dos direitos aduaneiros a diversos grupos de materiais não cobertos pelo Acordo.

\subsubsection{Preservação do patrimônio cultural}

Certo numero de instrumentos internacionais relativos à preservação do patrimônio cultural contem dispositivos que autorizam os Estados signatários a tomar medidas que seriam normalmente consideradas incompatíveis com o artigo XI do GATT de 1994 se não fosse a exceção do Artigo XX de (f) relativa à proteção dos tesouros nacionais. Entre estes instrumentos, destaquemos:

- A Convenção da UNESCO para a proteção de bens culturais em caso de conflito armado, adotada em Haia no dia 14 de maio de 1954 e que entrou em vigor no dia 7 de agosto de 1956.Esta convenção se refere a salvaguarda e ao respeito dos bens culturais em caso de um conflito armado; a proibição de exportar os bens culturais de um território 
ocupado e a obrigação de retornar esses bens para dentro do território do Estado de onde eles foram exportados.

- A Convenção da UNESCO sobre as medidas a tomar para proibir e impedir a importação, a exportação e o translado de propriedades ilícitas de bens culturais, adotada em Paris no dia 14 de novembro de 1970, que se refere a proteção dos bens culturais contra o roubo, a exportação ilícita e a alienação arbitraria.

\subsubsection{Proteção da propriedade intelectual}

Apesar da primazia recente do 'TRIPS, em razão principalmente do caráter regulatório do seu sistema de solução de controvérsias e do fato que suas normas regulem precisamente a interface entre o comercio internacional, é importante sublinhar um certo número de instrumentos precursores negociados pela comunidade internacional no âmbito da Organização mundial da propriedade intelectual (OMPI), dos quais os mais importantes são:

- A Convenção de Berna para a proteção das obras literárias e artísticas, adotada pela OMPI em 1886, que contem uma série de dispositivos que definem o mínimo de proteção, bem como das dispositivos especiais para os países em desenvolvimento;

- A Convenção universal sobre o direito de autor, adotada em Genebra em 1952 e revista em Paris em 1971 sob a égide da UNESCO. A Convenção estipula as modalidades de um regime de proteção do direito de autor adequado a todas as nações;

- A Convenção internacional sobre a proteção dos artistas, de intérpretes ou de executantes, dos produtores de fonogramas e os organismos de radiodifusão, adotada em Roma em 1961 sob a égide da OIT, a OMPI e a UNESCO. A Convenção de Roma protege as representações ou execuções dos artistas intérpretes ou executantes, os fonogramas dos produtores de fonogramas e as emissões rádio difundidas dos organismos de radiodifusão;

- A Convenção para a proteção dos produtores de fonogramas contra a reprodução não autorizada dos seus fonogramas, estabelecida em Genebra sob a égide da OMPI em 1971. A Convenção protege um produtor de fonogramas que é nacional de um outro Estado que contrata contra a produção de cópias feitas sem o consentimento deste produtor e contra a distribuição destas cópias ao público.

Os instrumentos internacionais recentes relativos à proteção do direito de autor e outros direitos relacionados determinam, a título de apoio à criação, sobre a necessidade de 
introduzir novas regras internacionais para que respostas adequadas possam ser dadas às perguntas levantadas pelos recentes desenvolvimentos de natureza econômica, social, cultural e tecnológica. O desenvolvimento do comércio eletrônico e o crescimento rápido da Internet geram um desafio importante aos instrumentos existentes e mostram a necessidade de maior cooperação internacional. Dois acordos concluídos na OMPI desde o fim da Rodada Uruguai, mas que ainda não estão em vigor, o Tratado sobre as interpretações, as execuções $e$ os fonogramas adotado em 1996, que visa desenvolver e assegurar a proteção dos direitos dos artistas intérpretes ou executantes e dos produtores de fonogramas de maneira também eficaz e uniforme que possível ${ }^{7}$; e o Tratado sobre o direito de autor, concluído em Genebra no dia 20 de dezembro de 1996, ilustram este tipo de instrumento.

\section{Os Acordos Regionais}

\subsection{Acordos intra-OCDE}

\subsubsection{A União Européia}

Não faz muito tempo que a cultura e os produtos culturais começaram a receber um reconhecimento específico em direito comunitário (europeu). Até entrada em vigor do Tratado de união européia (Maastricht) em Novembro de 1993, nenhum dispositivo do Tratado de Roma de 1957 ou o Ato Único Europeu de 1986 fazia referência expressa à cultura ou aos produtos culturais. Esta situação não impediu, contudo que um certo número de queixas fossem depositadas durante este período no Tribunal europeu de justiça em relação a medidas nacionais no domínio cultural consideradas como obstáculo a livre circulação dos bens ou serviços culturais. Em quase todos os casos, estas intervenções foram julgadas incompatíveis com o direito comunitário.

\footnotetext{
${ }^{7}$ O seu preâmbulo lê-se do seguinte modo: "Desejosos para desenvolver e assegurar a proteção dos direitos dos artistas intérpretes ou executantes e os produtores de fonogramas de maneira também eficaz e uniforme que possível;" Reconhecendo a necessidade de instituir novas regras internacionais para dar respostas adequadas às perguntas levantadas pela evolução constatada nos domínios econômicos, sociais, culturais e técnicos; Reconhecendo que a evolução e a convergência das técnicas da informação e a comunicação têm uma incidência considerável sobre a produção e a utilização das interpretações ou execuções e o fonograma; Reconhecendo a necessidade de manter um equilíbrio entre os direitos dos artistas intérpretes ou executantes e os produtores de fonogramas e o interesse público geral, principalmente em matéria de ensino, investigação e acessos à informação, as Partes convêm que:... "' Voir http://www.ompi.org/fre/main.htm
} 
A entrada em vigor do Tratado de Maastricht marca, porém uma mudança importante. Além de certas referências de natureza essencialmente introdutórias consagradas à preservação da cultura e da identidade nacional dos Estados membros, um título específico sobre a cultura que comporta um artigo único, o artigo 128, agora numerado artigo 151, foi acrescentado e precisões foram trazidas em relação às ajudas a cultura e a conservação do patrimônio (artigo 92 (3) agora artigo 87 (3)). O artigo 151 prescreve no seu parágrafo 1, que a contribuição das Comunidades Européias para a promoção cultural far-se-á “dentro do respeito das diversidades nacionais e regionais e destacando a herança comum” e ao seu parágrafo 4 que as Comunidades "levarão em consideração os aspectos culturais nas suas ações em virtude de outros dispositivos do Tratado”. Mesmo se é difícil predizer qual tipo de impacto concreto estas dispositivos terão em futuro, pode-se detectar o reflexo de uma mudança importante de perspectiva relativa ao lugar que deve ocupar a cultura no âmbito comunitário.

Dito isto, uma certa ambigüidade persiste em relação ao tratamento atribuído aos produtos culturais no plano comunitário e o seu tratamento no plano internacional. É um tanto paradoxal, de fato, constatar que a subordinação destes aos princípios da livre circulação dos bens e os serviços no interior mesmo da Comunidade não encontra a sua sustentação no plano internacional onde não se hesitou, por exemplo, a exigir aos Estados membros que mantenham quotas contra os produtos audiovisuais estrangeiros ou de restringir a elegibilidade aos programas de ajuda a produção aos membros comunitários.

Entre os instrumentos comunitários que regulam o comércio transfronteiriço de produtos culturais, a Diretiva das Comunidades Européias sobre “A televisão sem fronteira”, que esteve na origem de tensões comerciais importantes entre a Europa e os Estados Unidos ao final da Rodada Uruguai, ocupa um lugar bem particular ${ }^{8}$.

Os Estados membros da União Européia têm nestes últimos anos elaborado vários instrumentos destinados a promover o desenvolvimento, a radiação e maior divulgação dos produtos culturais na Comunidade e para além das suas fronteiras. A sua diversidade é tanta reconhecimento do valor intrínseco da cultura como fonte realização dos povos e da

\footnotetext{
${ }^{8}$ Enquanto a Diretiva cobre os 15 Estados-Membros da União Européia, a Convenção cobre potencialmente 47 Estados europeus. Após a revisão importante em 1997 da Diretiva "Televisão sem fronteira", tinha passado a ser necessário, para conservar esta coerência entre a Diretiva e a Convenção no interesse da segurança jurídica dos Estados e os radiodifusores transfronteiriços, deve adequar a Convenção e a Diretiva. Ver http://conventions.coe.int/treaty/fr/Summaries/Html/171.htm
} 
integração européia; promoção dos produtos multimídias; preservação da missão de serviço público de radiodifusão; promoção de regimes de preços fixos do livro; promoção dos acordos de co-produção cinematográfica e audiovisual; livre circulação das pessoas que trabalham no setor cultural - que é difícil oferecer uma visão sintética. A relação abaixo descreve, no entanto alguns dos instrumentos comunitários cujo alcance refere-se mais diretamente à conversão comércio-cultura e cujo tratamento pode ser útil para a reflexão sobre o teor possível de um instrumento internacional sobre a diversidade cultural:

- Decisão do Parlamento Europeu e do Conselho, de 14 de Fevereiro de 2000, estabelecendo o programa “Cultura 2000”;

- Resolução do Conselho da União Européia e dos representantes dos governos dos Estados-Membros, reunidos no Conselho de 25 de Janeiro de 1999, relativo ao serviço público de radiodifusão;

- Resolução do Conselho da União Européia de 8 de Fevereiro de 1999 relativos ao regime de preços fixos do livro nas zonas lingüísticas transnacionais homogêneas;

- Resolução do Conselho, de 17 de Dezembro de 1999, sobre a promoção da livre circulação das pessoas que trabalham no setor da cultura.

Vários instrumentos comunitários confirmam, além disso, a importância que os Estados-Membros atribuem à co-produção audiovisual como meio de reforçar a criação e a expressão da diversidade cultural do espaço europeu. Foi o caso, por exemplo, da Decisão do Conselho da União Européia de 10 de Julho de 1995 sobre a criação de um programa de incentivo ao desenvolvimento e a distribuição de obras audiovisuais européias. (o programa diz «Mídia II - Desenvolvimento e distribuição») ${ }^{9}$. Este programa que expirava em 2000 foi substituído pelo plano “Mídia Plus - Desenvolvimento, Distribuição e Promoção” que cobriu o período 2001-2005 (Decisão do Conselho de 20 de Dezembro de 2000 sobre a criação de um programa de incentivo ao desenvolvimento, à distribuição e a promoção das obras audiovisuais européias).

2.1.2 O Acordo de Livre Comércio da América do Norte (NAFTA)

\footnotetext{
9 Jornal Oficial $\quad$ No.. $\quad$ L 321 do 30 30/12/1995 p. 0025 - 0032 : $\quad$ http://europa.eu.int/eurlex/fr/lif/dat/1995/fr_395D0563.html 
Concluído em 1993 e entrando em vigor 1 Janeiro de 1995, o Acordo de livre comércio da América do Norte, que vincula os governos do Canadá, dos Estados Unidos e do México privilegia uma abordagem com diferentes níveis de profundidade, conforme o ponto específico do tema. O Canadá reservou-se o direito de subtrair as suas indústrias culturais do escopo do acordo (sujeito a medidas de retaliação). O México aceitou as normas do acordo, com algumas restrições. Os Estados Unidos escolheram tratar o setor cultural no âmbito do acordo sem qualquer restrição.

O anexo 2106 do NAFTA estipula que os direitos e as obrigações previstos no artigo 2005 desse tratado, concernente ao domínio cultural, valerão para todos os membros, no caso Estados Unidos, Canadá e México, bem como para outros que, porventura, venham a se associar. Apesar de o artigo 2005 prever em seu parágrafo $1^{\circ}$ que “as indústrias culturais são isentas dos dispositivos do presente acordo, exceto haja estipulação expressa...”, o parágrafo $2^{\circ}$ do mesmo artigo reduz, consideravelmente, o alcance real desta isenção, dizendo que:

Apesar dos outros dispositivos do presente acordo, cada parte poderá tomar medidas de efeito comercial equivalente como reação a intervenções que seriam incompatíveis ao presente acordo, se não fosse pelo parágrafo $1^{\circ}$.

Este último dispositivo contradiz a afirmação do parágrafo $1^{\circ}$, ao possibilitar o não -cumprimento das obrigações das quais as partes encontram-se, em principio, isentas. Uma Parte ao adotar ou manter efetivamente uma medida relativa a uma indústria cultural incompatível com as exigências do NAFTA e não presente na isenção do artigo 2005 (1), permite que o artigo se torne permissivo na discrição da parte requerente, sem que haja outras formas de recorrer a medidas compensatórias. O México, que não compartilhava das mesmas preocupações do Canadá com as indústrias culturais, ficou satisfeito com um número limitado de reservas na área cultural a partir da compensação com capítulos do acordo tratando do comercio transfronteiriço dos serviços e do investimento.

Anexo 2106: Indústrias culturais:

Não obstante qualquer outro dispositivo do presente acordo, e tratando-se do Canadá e dos Estados Unidos, qualquer medida adotada ou mantida no que diz respeito às indústrias culturais, exceto disposição expressa do artigo 302 (Acessos aos mercados, Eliminação dos direitos aduaneiros), e qualquer medida de efeito comercial equivalente adotada em reação, será regulada no 
âmbito do presente Acordo exclusivamente pelas disposições do Acordo de livre comércio entre o Canadá e os Estados Unidos. Os direitos e obrigações que se aplicam entre o Canadá e qualquer outra Parte relativamente a estas medidas serão idênticos aos direitos e obrigações que são aplicáveis entre o Canadá e os Estados Unidos. ${ }^{10}$

É importante lembrar que o NAFTA, no seu artigo 2005, determina, em termos de indústrias culturais, que:

1. As indústrias culturais são isentas das disposições do presente acordo, salvo determinação expressa do Artigo 401 (Eliminação dos direitos aduaneiros), do parágrafo $4^{\circ}$ do artigo 1607 (cessão forçada de uma aquisição indireta) e dos artigos 2006 e 2007 do presente capítulo.

2. Apesar das outras regras do presente acordo, cada parte poderá tomar medidas que tenham um efeito comercial equivalente em reação a intervenções que seriam incompatíveis com o presente acordo, se não fosse pelo parágrafo 1.

\subsection{Acordos Norte-Sul : O Acordo de Cotonou}

O Acordo de Cotonou, assinado em 23 de Junho de 2000, mas ainda não em vigor, substitui a Convenção de Lomé entre a União Européia e os países ACP, que estabeleciam, na sua última versão, vários artigos pertinentes em matéria de interface comércio-cultura. O Acordo de Cotonou integra, igualmente, as normas que fazem do desenvolvimento cultural um objetivo integral da cooperação no âmbito do Acordo. É assim que o artigo 27 prescreve: no domínio da cultura, a cooperação visa:

a. integrar a dimensão cultural em todos os níveis da cooperação para o desenvolvimento;

b. reconhecer, preservar e promover os valores e as identidades culturais para favorecer o diálogo intercultural;

c. reconhecer, salvaguardar e valorizar o patrimônio cultural, apoiar o desenvolvimento das capacidades neste setor, e

d. desenvolver as indústrias culturais e melhorar as possibilidades de acesso ao mercado para os bens e serviços culturais. ${ }^{11}$

\footnotetext{
${ }^{10}$ http://www.juris.uqam.ca/docjur/intl/Alena/Chap17.htm

${ }^{11}$ http://europa.eu.int/comm/development/cotonou/agreement/agr13 fr.htm
} 


\subsection{Acordos Sul-Sul}

\subsubsection{Hemisfério ocidental}

(i) AEA - Associação dos Estados Antilhanos

- Convenção que cria a Associação dos Estados antilhanos, adotada em 26 de Julho de 1994. O preâmbulo convoca os Estados-Membros à nova era de cooperação e de relações culturais. A Convenção conclama os Estados-Membros a estabelecer, consolidar e reforçar a sua capacidade coletiva de atingir um desenvolvimento cultural sustentado, especialmente por meio de estruturas institucionais e formas de cooperação que sejam sensíveis às identidades culturais, às necessidades em matéria de desenvolvimento e aos sistemas normativos da região (Artigo 3). Do mesmo modo, estabelece um Conselho Ministerial como instância da Associação, o qual tem por objetivo constituir uma comissão sobre a ciência, a tecnologia, a saúde, a educação e a cultura.

- Declaração de São Domingos, adotada em 17 de Abril de 1999, e que pede esforços crescentes para defender as identidades culturais dos Estados-Membros e para proteger e promover as expressões culturais locais.

(ii) CARICOM - Mercado Comum e Comunidade do Caribe

- Tratado instituindo o Mercado Comum e Comunidade do Caribe, adotado em 4 de Julho de 1973, que fixa as modalidades de cooperação entre os Estados signatários no domínio da cultura. O desenvolvimento cultural é reconhecido como um dos objetivos centrais da Comunidade.

- Protocolo de emenda ao Tratado que institui o Mercado Comum e Comunidade do Caribe (Protocolo III - Política industrial), adotado em 13 de Junho de 1998, cujo objetivo é assegurar a proteção da propriedade intelectual pela preservação das culturas antilhanas locais e pela proteção legal das expressões do folclore e outros costumes tradicionais, bem como do patrimônio cultural, particularmente o das populações indígenas.

- Carta da sociedade civil para o Mercado Comum e Comunidade dos Caribes, adotada em 1992, que afirma que cada cultura tem uma dignidade e um valor que deve 
merecer o respeito; que qualquer indivíduo tem o direito de preservar e desenvolver a sua cultura; e que os Estados devem reconhecer a contribuição dos povos autóctonos no processo de desenvolvimento econômico e social.

\section{(iii) América Central}

- Mercado Comum da América Central (MCAC) - Protocolo Tegucigalpa, adotado em 3 de Dezembro de 1991. O Protocolo interessa-se à promoção e à proteção do desenvolvimento cultural. O seu artigo 12 cria uma comissão consultiva, cujo mandato consiste em promover o desenvolvimento das esferas econômicas, sociais e culturais da região e que associa o setor privado, os meios sindicais, universitários e culturais. O Protocolo prevê também mecanismos de acordo regional que tratam de questões culturais que têm incidências internacionais.

(iv) Comunidade Andina (União Aduaneira)

Codificação do Acordo de Cartagena, adotado em 10 de Março de 1996. O acordo diz que a integração constitui um mandato histórico, político, econômico, social e cultural para preservar a soberania e a independência dos Estados-Membros, além de convocá-los a empreender ações comuns para reforçar a identidade da região andina, principalmente por meio de programas e projetos relativos ao patrimônio cultural, histórico e geográfico da região (Artigos 148 e 149).

(v) Mercosul $^{12}$ (Mercado Comum do Sul)

Protocolo de integração cultural do MERCOSUL:

"Os Governos da República da Argentina, da República Federativa do Brasil, da República do Paraguai e da República Oriental do Uruguai, doravante denominados "Estados-Partes"

\footnotetext{
${ }^{12}$ Ver a Décision MERCOSUR/CMC/Déc., No 11/96 : http ://www.mre.gov.br/unir/webunir/bdmsul/zlc\&ua/ 1CMC/2DECISOE/1996/DEC96.HTM 
Tendo em vista os princípios e os objetivos enunciados no Tratado de Assunção, assinado em 26 de março de 1991, a criação em 1992 do Grupo cultural especializado 13 e o Memorando de Entendimento, firmado em Buenos Aires, em 15 de março de 1995, no âmbito da Primeira Reunião Especializada de Cultura;

Conscientes de que a integração cultural constitui um elemento primordial dos Processos de integração e que a cooperação e o intercâmbio cultural geram novos fenômenos e realidades;

Inspirados no respeito à diversidade das identidades $e$ no enriquecimento mútuo;

Cientes de que a dinâmica cultural é fator determinante no fortalecimento dos valores da democracia e da convivência nas sociedades;

Acordam:

\section{ARTIGO I}

1. Os Estados-Partes comprometem-se a promover a cooperação e o intercâmbio entre suas respectivas instituições e agentes culturais, com o objetivo de favorecer o enriquecimento e a difusão das expressões culturais e artísticas do Mercosul.

2. Para tanto, os Estados-Partes promoverão programas e projetos conjuntos no Mercosul, nos diferentes setores da Cultura, que definam ações concretas.

ARTIGO II

1. Os Estados-Partes facilitarão a criação de espaços culturais e promoverão a realização, prioritariamente em co-produção, de eventos culturais que expressem as tradições históricas, os valores comuns e as diversidades dos Estados membros do Mercosul.

2. Os eventos culturais contemplarão, entre outras iniciativas, o intercâmbio de artistas, escritores, pesquisadores, grupos artísticos e integrantes de entidades públicas e privadas vinculadas aos diferentes setores da Cultura.

ARTIGO IV

Os Estados-Partes promoverão a formação comum de recursos humanos envolvidos na ação cultural. Para tanto, favorecerão o intercâmbio de agentes e gestores culturais dos Estados-Partes em suas respectivas áreas de especialização.

ARTIGO VII

Os Estados-Partes recomendam a utilização de um Banco de Dados comum informatizado - confeccionado no âmbito do Sistema de Informação Cultural da América Latina e do Caribe - SICLAC -, que contenha calendários de atividades culturais diversas e relações de recursos humanos e estruturais disponíveis em todos os EstadosPartes.

\footnotetext{
${ }^{13}$ Pela Resolução No. 34/92, os países do MERCOSUL erigiram um "Grupo" cultural especializado a fim de promover e difundir a cultura dos Estados-Membros; de favorecer a compreensão mútua entre os valores culturais cada um.
} 
ARTIGO VIII

Cada Estado-Parte protegerá, em seu território, os direitos de propriedade intelectual das obras originárias dos outros EstadosPartes, de acordo com sua legislação interna e com os tratados internacionais a que tenha aderido ou venha a aderir e que estejam em vigor em cada Estado Parte.

ARTIGO IX

Os Estados-Partes fomentarão a organização e a produção de atividades culturais conjuntas para sua promoção em terceiros países.

ARTIGO XI

Os Estados-Partes estimularão medidas que favoreçam a produção, a co-produção e a execução de projetos que sejam considerados de interesse cultural.

\subsection{2. África}

(i) COMESA - Mercado Comum da África Oriental e Austral

O Tratado do COMESA, que entrou em vigor em 1994, visa à promoção da cooperação nos assuntos sociais e culturais, principalmente por meio da promoção turística. O seu artigo 15 estabelece um Comitê regulamentador sobre o trabalho, os recursos humanos, os assuntos sociais e a cultura. O artigo 143 do Tratado requisita a criação de programas de trocas culturais e desportivos, assim como a produção de emissões de televisão e de rádio aptas a promover o desenvolvimento cultural da região.

(ii) CEEAC - Comunidade Econômica dos Estados da África Central

Tratado para a criação da Comunidade econômica dos Estados da África central. Adotado em 19 de Outubro de 1983, este tratado trata da promoção do desenvolvimento em todos os domínios da atividade social e econômica, incluindo a cultura. O artigo 62 do tratado afirma a vontade dos Estados-Membros de promover todas as formas de expressão culturais que emanam da região a fim de aumentar a disseminação. Para isso, os Estados comprometem-se a preservar o patrimônio cultural da região; trocar idéias sobre os seus programas culturais respectivos, principalmente nos domínios da música, da literatura, do espetáculo, das artes, do esporte e do lazer; trocar obras cinematográficas e televisivas e 
programas de rádio; e desenvolver as suas infra-estruturas culturais para projetos de interesse comum.

(iii) CSAD - Comunidade sul-africana de desenvolvimento

A Comunidade possui diversos objetivos em matéria de cooperação cultural regional: consolidação das relações e das afinidades históricas, sociais e culturais entre os povos da região; reforço dos regimes de propriedade intelectual, cuja proteção é reconhecida como importante para o desenvolvimento das indústrias culturais; estabelecimento de festivais artísticos e culturais; e trocas de informações sobre as políticas e os programas culturais dos países da região.

\subsection{3. Ásia}

(i) ANASE - Associação das nações da Ásia do Sudeste

- Declaração da ANASE, ou Declaração de Bangkok, adotada em 8 de Agosto de 1967, reconhece as relações culturais entre os Estados do Sudeste asiático e afirma que um dos objetivos bases da Associação é acelerar o desenvolvimento cultural da região por meio de atividades comuns e de assistência mútua.

- Declaração de entedimento da ANSEA, adotada em 24 de Fevereiro de 1976, visa estender a cooperação na ANASE Ao domínio da cultura, principalmente por meio de programas de apoio aos escritores, artistas, universitários e representantes dos meios de comunicação social destinados a favorecer uma melhor identidade regional.

- Plano de ação de Hanoi, adotado em 1998, refere-se à preservação do patrimônio cultural da região e à organização de programas de troca destinados aos jovens e campos de imersão nas artes e na cultura.

- Comitê da ANASE sobre a cultura e a informação (CCI). Criado em 1978, o Comitê é responsável pelo dispêndio do dinheiro do Fundo cultural da ANASE, por exemplo, no domínio do desenvolvimento de uma presença regional na Internet ou a promoção de festivais de filmes realizados na região.

(ii) ASACR 5 - Associação Sul-asiática para a cooperação regional 
- Carta da Associação Sul-asiática para a cooperação regional. Adotada em 8 de Dezembro de 1985, visa uma aceleração do crescimento econômico, do progresso social e do desenvolvimento cultural; assim como uma colaboração ativa e uma assistência mútua nos domínios econômicos, sociais, culturais, técnicos e científicos.

- Declaração da Décima Cimeira do ASACR. Ocorrida em 31 de Julho de 1998, a Cimeira deu impulso à preparação de um plano de ação para interligar os institutos culturais nacionais e estabelecer um Centro cultural asiático a fim de promover as artes da região da Ásia do Sul.

\subsection{Código da liberação das operações invisíveis correntes da OCDE ${ }^{14}$}

O Código cobre toda uma série de serviços, inclusive os serviços audiovisuais, os quais são objeto de regras específicas, que autorizam, expressamente, contingenciamento das emissões e as subvenções à produção. Além disso, os signatários do Código são autorizados a fazer reservas em relação ao setor cinematográfico, o que vários membros da OCDE fizeram. Há um texto importante no Anexo V do Anexo A que diz: “Por razões de ordem cultural, os sistemas de ajuda à produção de filmes destinados a projeções em salas de cinema poderão ser mantido, exceto se estes sistemas falseiam de maneira apreciável a concorrência internacional sobre mercados de exportação.”

Este instrumento, teoricamente regulatório, não teve eficácia real por muito tempo, o que explica o fato de que países que são membros da OCDE há muito tempo, como a França, - que está em infração notória à rubrica H1 sobre os filmes, já que não fez reserva não tenham sido incomodados até o momento. O Secretariado da OCDE, no entanto, parece ter a vontade de fazer valer mais o caráter regulatório deste instrumento, o que representou, por exemplo, fonte de dificuldades reais quando da entrada da Polônia e da Eslováquia na OCDE.

\section{Os Acordos Bilaterais}

\subsection{Acordos bilaterais de livre comércio}

\footnotetext{
${ }^{14}$ http://www.oecd.org//daf/investment/legal-instruments/clioart.htm
} 
É interessante sublinhar a existência de normas que excluem inteira ou parcialmente o setor cultural em diversos acordos bilaterais sobre o comércio. É assim que os dois acordos de livre comércio bilaterais concluídos pelo Canadá com o Chile, de um lado, e com o Israel, de outro, contêm, cada um, uma cláusula de exceção cultural que se pode qualificar de absoluto. Isso porque exclui totalmente os produtos culturais do alcance destes acordos (excetuando as tarifas aplicadas aos bens culturais) ${ }^{15}$ e sua utilização não provoca medidas de efeito comercial equivalente, como no caso do NAFTA.

Pode-se, igualmente, mencionar o Acordo de livre comércio entre a União Européia e o México, no âmbito do qual existe uma verdadeira cláusula de exceção cultural. Esta cláusula foi introduzida pelo artigo 2.2.a da decisão 2/2001 do Conselho conjunto UE/México de 27 de Fevereiro de 2001. De acordo com esta disposição, o campo do acordo sobre serviços não cobre o audiovisual. A União Européia negocia a introdução da mesma cláusula de exceção nos seus acordos com o Chile, de um lado, e com o MERCOSUL, de outro.

\subsection{Acordos bilaterais de cooperação cultural}

No plano bilateral, os acordos de cooperação cultural prevêem a isenção dos direitos aduaneiros à importação de qualquer material destinado à cooperação cultural e técnic, se este material não for destinado a fins comerciais. (Por exemplo, o Acordo de cooperação cultural e técnica entre a França e a Malásia, assinado em Paris, dia 3 de Novembro de 1972, R.T.N.U. 26263.)

\subsection{Acordos bilaterais de co-produção cinematográfica e audiovisual}

Estes são muito numerosos para mencionar todos. As reservas feitas no artigo II do Acordo geral sobre o comércio dos serviços (GATS) dão uma boa idéia da sua importância numérica e qualitativa.

\footnotetext{
${ }^{15}$ Assim como o famoso dispositivo do acordo Canadá - Chile (anexo O06): "Nenhuma disposição do presente acordo será interpretada como que aplicável à medidas adotadas ou mantidas pela uma ou o outro das Partes relativamente às indústrias culturais, exceto disposição expresso do artigo C-02 (Acessos aos mercados Eliminação dos direitos aduaneiros)"ver http://www.dfait-maeci.gc.ca/tna-nac/reg-f.asp")
} 


\subsection{Acordos bilaterais sobre investimento}

Todos os acordos bilaterais de investimento concluídos pelo Canadá desde 1993 possuem uma cláusula que exclui totalmente os produtos culturais do seu alcance. O texto seguinte, tirado do Acordo entre o governo do Canadá e o governo do reino da Tailândia sobre a promoção e a proteção do investimento, ilustra este tipo de cláusula:

Os investimentos efetuados nas indústrias culturais são isentos dos dispositivos do Acordo. "Indústrias culturais" designa as pessoas, físicas ou (jurídicas, que se dedicam a uma ou outra das seguintes atividades: a) a publicação, a distribuição ou a venda de livros, de revistas, de periódicos ou de jornais, sob forma impressa ou explorável por máquina, à exclusão contudo da única impressão ou composição destas publicações; b) a produção, a distribuição, a venda ou a apresentação de filmes ou de gravações em vídeo; c) a produção, a distribuição, a venda ou a apresentação de gravações musicais ou de vídeo; d) a edição, a distribuição ou a venda de composições musicais sob forma impressa ou explorável por máquina; ou e) as radiocomunicações cujas transmissões são destinadas a ser captadas diretamente pelo grande público, e todas as atividades de radiodifusão, teledifusão e de distribuição a cabo e todos os serviços das redes de programação e de divulgação por satélite.

\section{Considerações finais sobre a primeira questão}

Os instrumentos internacionais, multilaterais, regionais ou bilaterais, capazes de regulamentar de uma maneira ou de outra o comércio dos produtos culturais, tomam numerosas formas - declarações, resoluções, planos de ação, recomendações, princípios, linhas diretrizes, cartas, protocolo, convenções e tratados. Mesmo que, às vezes, seja difícil estabelecer uma demarcação clara entre estes diversos tipos de instrumentos, pode-se, no entanto, agrupá-los em duas categorias distintas. A primeira engloba os instrumentos considerados não regulatórios, ou seja, declarações, resoluções, planos de ação, recomendações, princípios e linhas diretrizes. É neste último que se encontram, sobretudo, os instrumentos de vocação, principalmente cultural. A segunda categoria compreende os instrumentos regulatórios: cartas, protocolos, convenções e tratados; ela agrupa praticamente todos os instrumentos cujo principal objetivo é comercial. 
Uma comparação das abordagens cultural e comercial sugere, de fato, que as prioridades são freqüentemente invertidas. A prioridade da abordagem comercial refere-se à liberalização completa (embora progressiva e ordenada) das trocas, bem como à eliminação dos obstáculos ao investimento, com algumas poucas exceções. Nesse sentido, as preocupações culturais não saberiam impedir esta liberalização. Na abordagem cultural, o desenvolvimento da troca acompanha o das culturas, mas não se sobrepõe a este último. Uma verdadeira troca cultural supõe por definição a existência de culturas distintas.

Tamanha diferença de perspectiva está no centro do debate em curso sobre a cultura e o comércio. Isso explica as preocupações crescentes que se expressam a respeito do tratamento dos bens e serviços culturais nos acordos comerciais, e o sentimento de insegurança inegável gerado nestes últimos anos pela liberalização das trocas e do investimento e, de maneira mais geral, pela mundialização. Há boas razões para crer que a mediação das tensões inerentes ao comércio e à cultura poderia utilmente fazer-se por meio do desenvolvimento de um instrumento internacional concernente à diversidade cultural.

Não é surpresa, nesse âmbito, constatar que, dos instrumentos analisados aqui, os que se dirigem de forma mais direta ao centro da problemática comércio-cultura e permitem identificar os principais parâmetros de um eventual instrumento internacional - acesso ao mercado, subvenções, liberalização dos obstáculos ao investimento, obrigações de resultado, proteção da propriedade intelectual, liberalização dos serviços com conteúdo cultural, mobilidade dos inventores, regulação das controvérsias - emanam essencialmente da esfera comercial. O que falta em contrapartida, é um instrumento que apresentaria um ponto de vista cultural articulado sobre esta problemática, uma vez que os instrumentos culturais existentes não se interessam, praticamente nunca, pela problemática comércio-cultura.

Dito isto, um rápido apanhado sobre diversos instrumentos comerciais descritos por este texto permite constatar a ausência de verdadeiro consenso sobre a maneira de abordar o binômio comércio-cultura. De maneira geral, os textos relativos à circulação ou ao comércio dos produtos culturais podem ser agrupados em duas categorias. Aparecem, de um lado, textos que estabelecem ou dão lugar a um tratamento de exceção para estes produtos nos acordos comerciais e, de outro lado, os que visam facilitar a circulação dos bens em questão eliminando os obstáculos às trocas. Com isso, fica imposta a constatação de que o direito de proteger uma produção cultural nacional ameaçada ainda não é uma coisa adquirida, ainda 
que a idéia de intervenções estatais com objetivos claramente culturais infringindo os princípios da livre concorrência comece a ser aceita.

Tabela recapitulativa

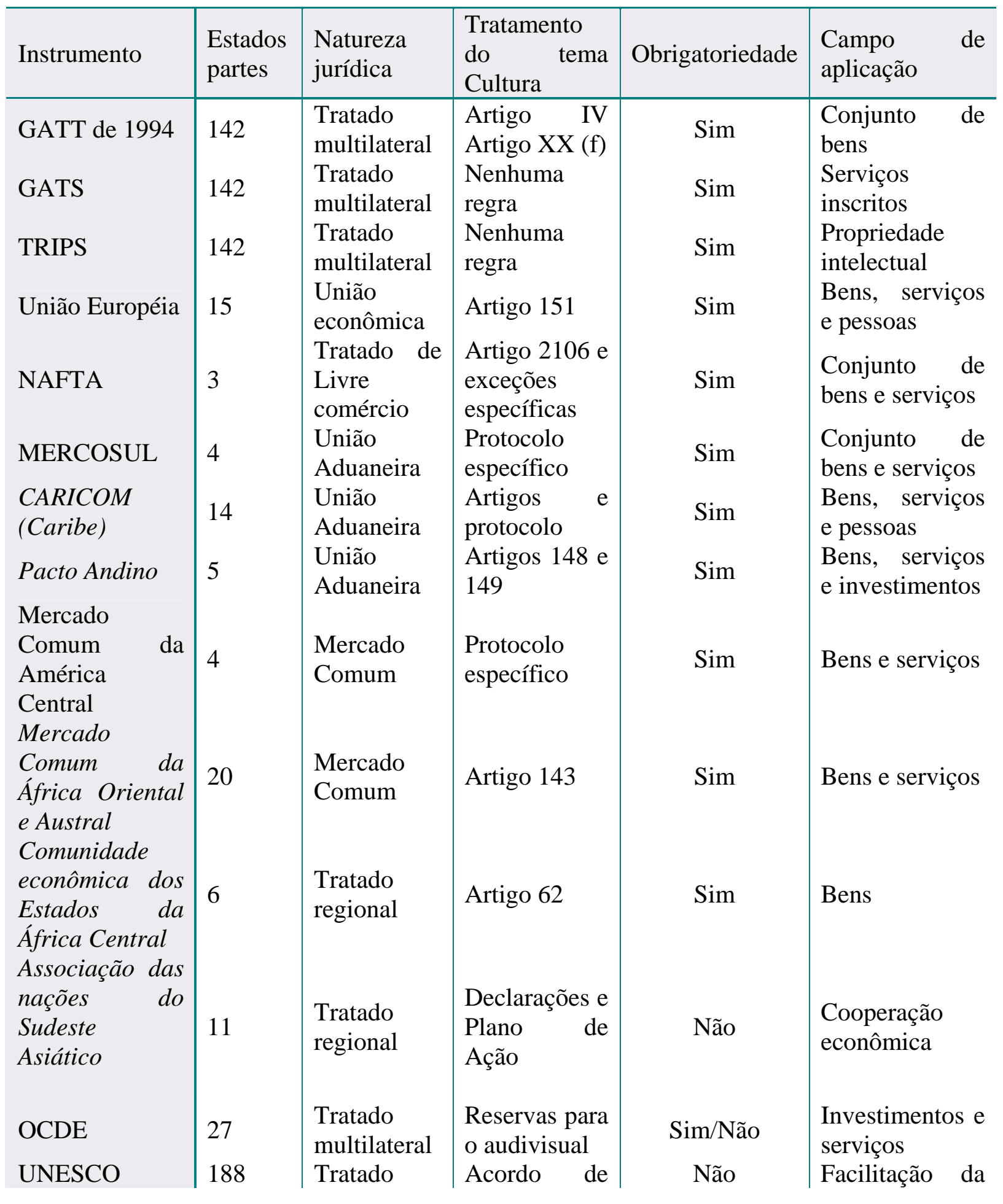




\begin{tabular}{|c|c|c|c|c|c|}
\hline UNESCO & idem & $\begin{array}{l}\text { multilateral } \\
\text { Idem }\end{array}$ & $\begin{array}{l}\text { Florença } \\
\text { Conventions } \\
\text { de } 1954 \text { et de } \\
1970\end{array}$ & Não & $\begin{array}{l}\text { circulação de } \\
\text { produtos } \\
\text { culturais } \\
\text { Preservação do } \\
\text { patrimônio }\end{array}$ \\
\hline UNESCO & idem & Idem & $\begin{array}{l}\text { Convenções } \\
\text { de Genebra } \\
\text { etc. }\end{array}$ & Sim & $\begin{array}{l}\text { Propriedade } \\
\text { intelectual }\end{array}$ \\
\hline UNESCO & idem & Idem & $\begin{array}{l}\text { Declarações e } \\
\text { Resoluções }\end{array}$ & Não & $\begin{array}{l}\text { Cooperação } \\
\text { cultural }\end{array}$ \\
\hline OMPI & 177 & $\begin{array}{l}\text { Tratado } \\
\text { multilateral }\end{array}$ & Convenções & Sim & $\begin{array}{l}\text { Direitos } \\
\text { autorais }\end{array}$ \\
\hline
\end{tabular}

\section{PARTE II. Identificação das soluções jurídicas que podem permitir a adoção de um instrumento regulatório internacional}

O exame dos instrumentos internacionais que regulam o comércio dos bens e serviços culturais revelou a existência de uma distinção fundamental entre os instrumentos considerados regulatórios (convenções, tratados, cartas, protocolos) e os que não o são (declarações, resoluções, planos de ação, recomendações). A adoção de um instrumento internacional normativo no domínio cultural exclui, por conseguinte, e, a priori, o recurso a instrumentos do tipo declarações, resoluções ou recomendações. Dito isto, é necessário precisar que o processo que deve conduzir à adoção de um instrumento regulatório no domínio cultural pode comportar etapas, como, por exemplo, a adoção, inicialmente, de uma declaração sobre a diversidade cultural. Existe o risco, contudo, que isso ocorra somente se a realização da primeira etapa mostrar-se mais complexa do que previsto, e se a etapa seguinte, a da negociação de um instrumento regulatório, for adiada ou mesmo abandonada por falta de um apoio suficiente.

Para que um número suficiente de Estados aceite comprometer-se na negociação de um instrumento internacional regulatório em matéria de diversidade cultural, é necessário que este último responda a necessidades claramente identificadas, preencha um vazio no plano jurídico, tenha objetivos claros e ofereça, no plano normativo, soluções adequadas e realizáveis. Antes de ver nossa posição nesse aspecto, torna-se necessário responder à questão prévia sobre qual organismo acolheria tal negociação, pergunta que pode revelar-se importante para o sucesso de uma empreitada tão complexa. 


\section{Uma questão preliminar sobre o organismo sede da norma}

Tratando-se da ligação do instrumento em questão a uma organização internacional, as hipóteses são bem limitadas. A organização mais provável é, naturalmente, a UNESCO. Essa sugestão tem seus méritos, mas levanta também certos problemas. Do lado positivo, pode-se mencionar o fato desta organização, além de ter como domínio próprio de intervenção o da cultura, já seja sensível à questão da preservação da diversidade cultural (colóquio de Junho de 1999 em Paris, projeto de declaração sobre a diversidade cultural), bem como ao seu caráter multilateral e à sua forte presença nos países em desenvolvimento. Em contrapartida, um obstáculo a ser vencido é o da marcante ausência dos Estados Unidos na Organização. O problema não é que a conclusão de um acordo sem os Estados Unidos diminuiria o interesse nesse instrumento - veremos mais adiante que isso não é o caso - mas que a conclusão de tal acordo poderia ser percebida no seio da Organização como um obstáculo à eventual reintegração dos Estados Unidos, que se opõem radicalmente a que esta extrapole seu campo de intervenção para agir no domínio do comércio.

O fato de que a UNESCO, a exemplo do Conselho da Europa e da Francofonia, decidiu adotar uma declaração sobre a diversidade cultural parece, à primeira vista, facilitar uma possível ligação do instrumento à UNESCO. Contudo, resta saber se os seus membros vão querer ir além de tal declaração. O Plano de ação anexado a Declaração Universal sobre a diversidade cultural, adotada na $31^{\mathrm{a}}$ sessão da Conferência geral da UNESCO, em Novembro de 2001, prevê, no seu artigo $1^{\circ}$, o adiantamento “da reflexão relativa ao cabimento de um instrumento jurídico internacional sobre a diversidade cultural”, mas é difícil dizer o que isso abrange. Se os membros da UNESCO tiverem que escolher ficar com uma simples declaração, então não haveria outra escolha que de proceder fora do quadro da UNESCO.

Fora da UNESCO, poucas organizações internacionais parecem em condições, atualmente, de abrigar um instrumento como o que é desejado aqui. A única hipótese que parece possível é a Rede internacional sobre a política cultural (RIPC), que é uma corte internacional onde os ministros nacionais responsáveis pela cultura podem trocar idéias sobre os novos desafios e as questões de política cultural que se desenham no horizonte, e pensar em meios integrados para favorecer a diversidade cultural num contexto cada vez mais mundializado. Mas o RIPC funciona de maneira bastante informal e é difícil estabelecer se ele 
tem condições de abrigar um instrumento sobre a diversidade cultural. Abstraindo-se a rede em questão, resta ainda a possibilidade de um instrumento internacional não ligado a uma organização em especial, como é possível encontrar sobre a questão ambiental. Na ausência de um apoio institucionalizado, é necessário poder contar com o apoio de um número suficientemente importante de Estados convencidos da necessidade de um instrumento internacional sobre a diversidade cultural, e prontos a comprometerem-se profundamente com sucesso do projeto, o que lhe conferiria uma possibilidade de sucesso.

\section{A necessidade de um instrumento internacional regulatório sobre a diversidade cultural}

A necessidade de um novo instrumento internacional regulatório sobre a diversidade cultural faz-se sentir, essencialmente, em razão da ameaça à diversidade cultural e da falta de respostas adequadas à estas ameaças pelos instrumentos culturais existentes.

\subsection{As ameaças que pesam sobre a diversidade cultural}

A diversidade cultural está ameaçada de duas formas. A primeira remete-se ao fato de que a originalidade e a pluralidade das identidades que caracterizam os grupos e as sociedades humanas são marginalizadas por um processo de liberalização das trocas cujo resultado final não é muito evidente. O processo em questão, centrado essencialmente sobre a concorrência, tende a impor um mesmo molde comercial aos múltiplos anseios dos cidadãos nos diversos domínios da atividade humana e induz a novas formas de organização social que reavaliam não somente as maneiras de fazer e de agir tradicionais, mas também os valores compartilhados. Deve-se reconhecer que toda cultura nacional, se quer manter-se viva, deve adaptar-se a uma variedade de mudanças tanto internas como externas.

O verdadeiro problema acarretado pela mundialização, no que diz respeito às culturas nacionais, é saber se as mudanças que provocam nos valores, nas maneiras de ser e fazer, afetam a possibilidade de "promover e manter um espaço público plural pelo qual os 
cidadãos podem ter acesso e participar da vida cultural, ela mesma necessária para a vida pública” ${ }^{16}$, em outras palavras, a possibilidade de manter uma expressão cultural distinta.”

A segunda ameaça à diversidade cultural deve-se ao impacto que a liberalização das trocas tem sobre a capacidade dos Estados de manter uma expressão cultural distinta; estes últimos estando impedidos de adotar normas que obstruam, diretamente ou indiretamente, a circulação dos bens e os serviços culturais. Esta última ameaça é ainda mais alarmante,uma vez que os inventores e os intermediários culturais desempenham um papel crucial quanto à adaptação das culturas à mudança, na medida em que criam um espaço de confrontação crítico entre valores nacionais e valores estrangeiros, entre valores e comportamentos do passado e perspectivas de futuro. Preservar a diversidade das expressões culturais, nesse ponto de vista, é preservar a diversidade cultural própria; a primeira desempenhando um papel instrumental em relação à segunda. Esta é a razão pela qual o novo instrumento internacional sobre a diversidade cultural deve dedicar-se, fundamentalmente, à preservação da diversidade das expressões culturais.

A ameaça que a liberalização das trocas faz pesar sobre a preservação da diversidade de expressões culturais esta longe de ser fictícia. Ela resulta primeiro, no plano jurídico, da pressão constante que se exerce, nas negociações, para obter dos Estados a liberalização completa do comércio cultural. Este contexto inclui as subvenções, as quotas, as restrições ao investimento estrangeiro, as medidas regulamentares, etc. ${ }^{17}$ Infelizmente, quando um Estado desiste de recorrer a estes tipos de intervenções, não pode mais voltar atrás e não estará autorizado a fomentar suas manifestações culturais. Recentemente, a Nova Zelândia, após ter-se comprometido nas negociações da Rodada Uruguai a não mais fazer uso de restrições quantitativas no setor dos serviços audiovisuais (que limitam efetivamente a sua margem de manobra a simples subvenções), voltou atrás e anunciou, no programa de atividade do seu ministério da Cultura para 2001-2002, a sua intenção de reintroduzir quotas em matéria de rádio e televisão ${ }^{18}$. Muito rapidamente, os Estados Unidos fizeram esta ultima

\footnotetext{
${ }^{16}$ Ver RABOY, Marc, Ivan BERNIER, Florian SAUVAGEAU et Dave ATKINSON. Desenvolvimento cultural e mundialização da economia, Québec, Instituto quebequiano de pesquisa sobre a cultura, 1994, p. 77 ,

${ }^{17}$ Ver designadamente a este respeito o estudo de François RODA, "o apoio às indústrias culturais na área de língua francesa:" modalidades, desafios e incidências ", Agência Francophonie:" http://confculture.francophonie.org/DocComplement/ Rouet.cfm?id_groupe=2\&id_rubrique=15

${ }^{18}$ http://www.mch.govt.nz/publications/dfr2001/MCH 2001 DFR.pdf
} 
compreender que aquilo não era mais possível. ${ }^{19}$

Compromissos assumidos e não cumpridos, podem resultar em reclamação por parte do membro que se considera lesado. Algumas vezes, o problema pode ser resolvido na fase das consultas, como foi o caso do protesto dos Estados Unidos contra a Turquia, em razão da taxa sobre a entrada de cinema instituída por este último, considerada discriminatória. Outras vezes, porém, a reclamação pode acarretar a constituição de um grupo especial, e, eventualmente, uma decisão do Órgão de Apelações, como foi o caso do conflito opondo os Estados Unidos e o Canadá no conflito dos periódicos. A decisão tomada, porém, pode, na ocasião, ter conseqüências que excedem em muito o quadro do conflito que a originou. Dois pontos levantados no caso Canadá - Certas medidas relativas aos periódicos podem nos fazer pensar a esse respeito. Tratando-se primeiro de saber se os periódicos deveriam ser considerados como bens ou serviços, o Órgão de Apelação decidiu que um "periódico é uma mercadoria composta de dois elementos: o conteúdo editorial e o conteúdo publicitário. O um e o outro podem ser considerados como tendo características de um serviço, mas juntos eles formam um bem material - o periódico propriamente dito”. Por meio de tal afirmação, pode-se, facilmente, chegar à conclusão que não somente os periódicos, mas também o filme, as emissões de televisão registradas em vídeo, o $\mathrm{CD}$, constituem bens, e não serviços. O segundo ponto, a sublinhar, refere-se à seguinte conclusão do Órgão de Apelação quanto ao alcance do artigo III: 8 (b) em matéria de subvenções:

O artigo III:8 b) limita por conseguinte as subvenções aos produtores, em relação os pagamentos efetuados após a cobrança das taxas ou nos pagamentos, além disso compatíveis com o artigo III. Esta distinção entre as regras relativas às taxas, por exemplo, as isenções ou reduções de taxas, $e$ as regras relativas às subvenções justificava-se do ponto de vista econômico e político. Ainda que o produto de taxas não discriminatórias sobre produtos pudesse ser utilizado para atribuir ulteriormente subvenções, $o$ produtor nacional, como os seus concorrentes estrangeiros, deveria pagar as taxas devidas sobre os produtos. A distinção entre estas duas categorias de regras contribuía para aumentar a transparência."20

Esta afirmação do Órgão de Apelação significa que as subvenções, atribuídas sob a forma de diminuição de taxa, não são compatíveis com o GATT de 1994 e correm o risco de ter um impacto que excede, claramente, o quadro da questão dos periódicos. Vários países

\footnotetext{
${ }^{19}$ Ver Office of the United States Trade Representative, National Trade Estimate of Foreign Trade Barriers.

${ }^{20}$ Relatório adotado em 19 de Junho de 1992, IBDD, S39/233, parágrafo 5.10.
} 
poderiam ter que reexaminar a sua maneira de conceder ajuda financeira às indústrias culturais, porque tais subvenções são bastante freqüentes no domínio cultural.

\subsection{As lacunas dos instrumentos existentes no plano jurídico}

A vasta maioria dos instrumentos que regulam, de uma maneira ou de outra, o comércio dos bens e serviços culturais ignora a problemática da preservação da diversidade das expressões culturais em contexto de mundialização crescente da economia. Duas lacunas em especial merecem ser sublinhadas a esse respeito.

\subsubsection{Ausência de uma visão global do impacto da mundialização na diversidade cultural}

A lacuna mais séria e mais evidente reside no fato de os instrumentos culturais existentes tratarem do problema da preservação da diversidade cultural de maneira parcial, por pontos de vista tão diversos quanto os direitos da pessoa, os direitos de propriedade intelectual, a proteção do patrimônio, os direitos lingüísticos, o pluralismo cultural, o desenvolvimento cultural, a cooperação internacional em matéria cultural, etc... Porém, esta ausência de uma visão global requerida para assegurar a preservação e a promoção da diversidade cultural constitui uma deficiência essencial, quando do momento de lidar com a questão do tratamento dos produtos culturais nas negociações comerciais internacionais.

\subsubsection{Avaliação inadequada do desequilíbrio das trocas culturais no plano internacional}

Este desequilíbrio, particularmente importante no setor audiovisual, refere-se igualmente ao comércio cultural dos países em desenvolvimento e ao comércio cultural dos países desenvolvidos. No caso dos países em desenvolvimento, confrontados em sua maioria com um mercado interno com recursos limitados, encontram-se, mais freqüentemente, dependentes do consumo de produtos culturais importados, que provêm de alguns países desenvolvidos ou em desenvolvimento. De acordo com uma pesquisa mundial realizada em Setembro de 1999 pela UNESCO, a África, com uma média tão fraca de 42 produções locais, importava mais de 2.811 filmes por ano e, nos países árabes, os cinemas projetavam dez vezes 
mais filmes estrangeiros que filmes nacionais ${ }^{21}$. Na América Latina, o desequilíbrio é ainda mais flagrante como, por exemplo, no Chile e na Costa Rica, onde os filmes hollywoodianos representam 95\% do mercado interior ${ }^{22}$. Estes poucos dados já são suficientes para mostrar a amplitude do desequilíbrio nas trocas entre países em desenvolvimento e países desenvolvidos.

Contudo, o desequilíbrio do comércio internacional dos filmes, no caso dos países em desenvolvimento, é um pouco compensado por trocas regionais mais equilibradas. É assim que vários países de produções médias aproveitam um mercado periférico tradicional, definido pela proximidade geográfica ou por uma identidade cultural e lingüística comum. Este esquema geográfico é perceptível na Ásia, onde os países exportadores como a Índia, o Japão e Hong-Kong podem ocupar mais de um terço dos mercados vizinhos. Os filmes indianos, por exemplo, representam 35\% dos longas-metragens projetados em Bangladesh, enquanto Hong-Kong produzem 38\% dos filmes mostrados no Paquistão.

A situação não é tão diferente nas trocas entre países desenvolvidos, onde a dominação marcada de um ou alguns países no mercado doméstico realiza-se, geralmente, em detrimento não somente da produção nacional, mas também das outras produções estrangeiras. No caso da televisão, como no do cinema, a possibilidade para os espectadores europeus de descobrir a variedade da produção européia e mundial é limitada, consideravelmente, pela fraca divulgação dos filmes e programas de televisão que não sejam americanos ou nacionais, como mostram as tabelas apresentadas no Anexo 1. O mesmo ocorre na Austrália e no Canadá (Anexo 2). Por outro lado, pode-se falar também de um desequilíbrio no consumo de produtos audiovisuais nos Estados Unidos, na medida em que apenas 3 a 5\% do consumo em questão vão para produções estrangeiras de várias origens diferentes.

\section{Os objetivos do novo instrumento sobre a diversidade cultural}

\footnotetext{
${ }^{21}$ Ver http://www.unesco.org/culture/industries/cinema/html_fr/survey.shtml

${ }^{22}$ Ver http://www.unesco.org/culture/industries/cinema/html_fr/survey.shtml

PRISMAS: Dir., Pol.Pub. e Mundial., Brasília, v.4, n, 1, p 215-272, jan/jul. 2007
} 
Os objetivos de um instrumento internacional encontram-se normalmente enunciados no seu preâmbulo ${ }^{23}$. Podem-se distinguir os objetivos imediatos e os de longo prazo. Os primeiros desempenham geralmente um papel instrumental (a liberalização das trocas, por exemplo, no caso da OMC) em relação aos segundos que exprimem, antes de tudo, o objetivo final do instrumento ou, se preferirmos, os resultados esperados da realização dos objetivos imediatos (o aumento dos níveis de vidas, a realização do pleno emprego, o crescimento do comércio, no caso da OMC). Tratando-se do novo instrumento sobre a diversidade cultural, uma distinção poderia ser efetuada com base nas constatações formuladas nas páginas precedentes.

O objetivo imediato do novo instrumento seria assegurar a preservação e a promoção da diversidade das expressões culturais perante o desafio da mundialização. A realização deste primeiro objetivo relaciona-se ao fato de ela mesma ser essencial à preservação e à promoção da diversidade das culturas e, por conseguinte, à diversidade cultural. É importante precisar que o objetivo em questão tem um caráter essencialmente cultural, pois responde à problemática que é, primeiramente, cultural. Isso deverá refletir-se na formulação do conteúdo normativo do instrumento.

Se a preservação e a promoção da diversidade das expressões culturais são os objetivos imediatos do novo instrumento, explica-se a razão pela qual a preservação da diversidade cultural constitui o objetivo final. Este objetivo deverá ser destacado no novo instrumento sublinhando a relação estreita que ele mantém com outros objetivos sociais, como a expressão democrática, a coesão social e o desenvolvimento econômico. Isso sem fazer, no entanto, do instrumento um texto relativo ao governo democrático ou ao desenvolvimento econômico como tal. Precisar-se-á, a esse respeito, que a preservação e a promoção da diversidade cultural são consideradas como um objetivo de política nacional, fazendo assim eco ao direito reconhecido dos membros de intervir para responder a objetivos de política nacional, conforme previsto no Acordo geral sobre o comércio dos serviços. O preâmbulo seria o lugar adequado para se fazer isso, a menos que se escolha inserir no acordo uma primeira parte consagrada aos "princípios gerais”. Além disso, a preservação da diversidade cultural implica, no plano externo, abertura à produção cultural estrangeira, e, por

\footnotetext{
${ }^{23}$ O preâmbulo da Declaração universal sobre a diversidade cultural adoptada pela UNESCO em Novembro de 2001 oferece um exemplo muito relevante que poderia ser o preâmbulo de um instrumento internacional sobre a diversidade cultural.
} 
isso, seria conveniente fazer surgir essa outra dimensão na formulação do objetivo final do instrumento.

\section{O Conteúdo normativo do novo instrumento sobre a diversidade cultural}

O conteúdo normativo do novo instrumento poderia ser estruturado em função dos tipos de intervenções que exigem a realização do objetivo de base do instrumento, a saber, a promoção e a preservação da diversidade cultural. O instrumento proposto poderia distinguir as três categorias de intervenções - as ligadas ao respeito aos direitos individuais em matéria cultural (não discriminação, liberdade de expressão cultural, direito de participar da vida cultural da sua comunidade), as ligadas à promoção e ao desenvolvimento da expressão cultural nos Estados e, por último, as ligadas à preservação da diversidade cultural no contexto internacional (medidas positivas em prol dos países em desenvolvimento, direito do Estado de intervir em prol da preservação da sua própria identidade cultural quando esta é ameaçada, abertura sobre as culturas estrangeiras).

De maneira geral, a pergunta é como poderemos constatar se os compromisso assumidos pelas partes são, sobretudo, de natureza processual. O direito que lhes é reconhecido de tomar qualquer medida julgada necessária à promoção da diversidade das expressões culturais e à preservação da diversidade das culturas está acompanhado de um compromisso que corresponde a respeitar certas exigências, como a transparência, a proporcionalidade dos meios de intervenção em relação aos objetivos perseguidos e a abertura máxima à produção cultural estrangeira.

4.1 O primeiro tipo de intervenção normativa colocaria o instrumento no contexto dos direitos fundamentais da pessoa humana

O objetivo não é instaurar novas normas neste domínio, mas antes precisar a relação estreita entre o respeito aos direitos culturais e a preservação da diversidade cultural. O princípio de inicial poderia, com algumas modificações, ser o enunciado no artigo 1.2 da Declaração sobre a diversidade cultural do Conselho da Europa que diz: "a diversidade cultural não pode exprimir-se na ausência das condições necessárias para a livre expressão criadora e a liberdade de informação que existe em todas as formas de trocas culturais, 
principalmente as operadas pelos serviços audiovisuais”. Em seguida, poderia ser mencionado o compromisso das Partes de não manter distinção, exclusão, ou preferência injustificadas em função da pertinência de uma comunidade cultural respeitar a liberdade de expressão cultural e o direito de cada indivíduo de participar da vida cultural da sua comunidade. Finaliza com uma afirmação de que nenhum dos dispositivos do acordo poderá ser interpretado de maneira a limitar ou derrogar os direitos garantidos pela Declaração universal dos direitos do homem, pelo Pacto internacional relativo aos direitos civis $e$ políticos, e pelo Pacto internacional relativo aos direitos econômicos, sociais e culturais.

A importância de tal desenvolvimento no plano normativo é limitar o alcance do princípio básico que se sobrepõe ao resto das normas, a saber, o princípio que cada Estado continua livre para tomar as medidas necessárias para assegurar, por um lado, uma expressão cultural dinâmica e diversificada no território nacional e para preservar, por outro lado, a diversidade cultural no plano internacional. O exercício deste direito, visivelmente, não deve ir contra os direitos fundamentais da pessoa. Tal referência aos direitos da pessoa poderia ser um obstáculo à adesão de alguns Estados? Isso é possível, mas as vantagens, neste caso, são maiores que os inconvenientes. Seria no mínimo embaraçoso se o novo instrumento servisse de pretexto para intervenções discriminatórias no plano cultural.

4.2 O segundo tipo de intervenção normativa teria por objeto a ação reguladora para assegurar uma expressão cultural dinâmica e diversificada no território nacional

Em contexto em que a capacidade de intervenção do Estado em matéria cultural é limitada, o instrumento deveria, em primeiro lugar, reconhecer o direito dos Estados de tomar todas as medidas necessárias para assegurar a promoção e a preservação da diversidade cultural perante o desafio da mundialização, pois isso implicaria, por um lado, a preservação e na promoção das culturas existentes com a sua expressão cultural e, por outro lado, a abertura mais ampla às outras culturas. Esse é o objetivo primordial do novo instrumento. $\mathrm{O}$ acordo, neste ponto, teria um caráter regulatório, em que cada Estado membro se comprometeria a reconhecer o direito dos outros Estados membros de decidir, em função do seu próprio contexto, a natureza das medidas a tomar. Ao mesmo tempo, no entanto, cada Estado comprometer-se-ia a fazer com que as suas intervenções preservassem um acesso, que fosse o mais amplo possível, às outras culturas. Tal reconhecimento de princípio do direito dos 
Estados de tomar as medidas necessárias para assegurar a preservação e a promoção da diversidade cultural, embora formulada aqui em termos culturais, encontra certa relação, como veremos mais distante, com a linguagem jurídica da OMC. No Acordo de medidas sanitárias e fitossanitárias, por exemplo, prevê-se que "nenhum Membro deve ser impedido de adotar ou aplicar medidas necessárias à proteção da vida ou da saúde humana, animal ou vegetal, desde que tais medidas não sejam aplicadas de modo a constituir discriminação arbitrária ou injustificável entre Membros em situações com as mesmas condições, ou uma restrição velada ao comércio internacional”.

Em conformidade com o princípio precedente, o novo instrumento deveria, em seguida, relacionar os aspectos de política cultural que requerem uma atenção específica no âmbito da nova economia mundial e elaborar um catálogo de medidas que poderiam ser úteis para preservar e favorecer a diversidade cultural (Conselho da Europa, Declaração sobre a diversidade cultural, artigo 3.3.) O objetivo de tal exercício seria ilustrar como o princípio básico do instrumento pode transpor-se para situações concretas por um raciocínio que se mantém, essencialmente, cultural. Tratando-se das subvenções, por exemplo, as Partes poderiam ser chamadas a reconhecer que as subvenções desempenham um papel essencial na promoção e no desenvolvimento da expressão cultural de uma comunidade e que compete a cada Estado decidir a importância e a natureza destas subvenções, quer estas tenham a forma de uma transferência direta de fundos, de diminuição fiscal ou de qualquer outra forma de apoio. As subvenções em questão poderiam ser acessíveis a todos os produtores ou reservadas, unicamente, às produções nacionais. Nesse último caso, competiria ao Estado referido estabelecer o que constitui uma produção nacional. No que diz respeito à manutenção de empresas de serviço público nos setores de rádio e televisão, o instrumento poderia reconhecer o direito dos Estados de fornecer o financiamento de um serviço público de radiodifusão, na medida em que esse financiamento é atribuído aos organismos de radiodifusão para fins do cumprimento da missão de serviço público como foi conferida, definida e organizada por cada Estado-Membro (abordagem comunitária). Outros tipos de medidas poderiam, da mesma maneira, serem desenvolvidas, como as relativas ao controle da propriedade estrangeira no domínio cultural, as que impõem prescrições de resultado, etc. Em todos os casos, no entanto, as medidas normativas instauradas deveriam exigir que as intervenções regulatórias em prol do desenvolvimento da expressão cultural sejam 
transparentes, ou seja, claramente identificadas; insiram-se num quadro de intervenção, claramente, cultural e não limitem indevidamente o acesso à produção cultural estrangeira. Tais exigências, além de posicionar claramente as intervenções em questão numa perspectiva cultural, contribuiriam para tranqüilizar em relação à possibilidade de uma profusão destas intervenções para considerações diferentes das culturais.

4.3 O último tipo de intervenção normativa orientaria, mais particularmente, as medidas nacionais que visam influenciar os fluxos internacionais de intercâmbio cultural

As medidas nacionais vislumbradas neste último caso procuram garantir um espaço para uma produção cultural ameaçada pela invasão dos produtos culturais estrangeiros (quotas negativas), ou incentivar um acesso mais diversificado à produção cultural estrangeira (quotas positivas), ou ainda facilitar o acesso da produção nacional ao espaço cultural internacional (subvenções). Na medida em que estas intervenções têm por objetivo ampliar as opções, e não restringi-las, elas deveriam, no âmbito do instrumento, ser consideradas como justificadas, exceto quando aplicadas de forma a restringir indevidamente o intercâmbio cultural. Como as intervenções desta categoria, contrariamente às da categoria precedente, visam precisamente influenciar os fluxos internacionais de intercâmbio cultural e correm o risco de preocupar mais os produtores estrangeiros, elas requerem, deste ponto de vista, um controle mais rígido. O fato de diferenciar as intervenções da categoria 2, que são mais numerosas e não criam grandes dificuldades, e as intervenções da categoria 3, claramente mais raras, mas mais suscetíveis de levantar problemas, permite definir melhor o tratamento a ser dado a uma e outra categoria. Esta maneira de proceder nos faz lembrar da distinção feita no direito internacional econômico entre as subvenções ditas domésticas, que são autorizadas, mas podem resultar numa atitude contrária, e as subvenções à exportação, que são proibidas. Mas a distinção, no caso do instrumento, é fundada em considerações culturais, e não econômicas.

De maneira geral, como pode ser constatado, os compromisso assumidos pelas partes a esse respeito são primeiramente e, sobretudo, de natureza processual. O direito de tomar qualquer medida julgada necessária à promoção da diversidade das expressões culturais e à preservação da diversidade das culturas é acompanhado de um compromisso correlato de respeitar certas exigências, como a transparência, a proporcionalidade dos meios de 
intervenção diante dos objetivos perseguidos e a máxima abertura à produção cultural estrangeira.

\section{A implementação de um novo instrumento}

Se o novo instrumento deve ser regulatório, é conveniente examinar como o respeito a ele poderia ser assegurado. Isto levanta em primeiro lugar o problema do acompanhamento da implementação do instrumento e, em segundo lugar, o problema da solução das controvérsias suscetíveis de ocorrer entre os Estados-Membros em relação a sua implementação.

\subsection{O acompanhamento da implementação}

Para assegurar concretamente a sua implementação e favorecer um acordo entre os Estados-Membros no que diz respeito à realização dos objetivos perseguidos, o instrumento deveria incorporar um mecanismo de acompanhamento. A idéia mestra das propostas apresentadas a seguir é dar uma orientação mais “técnica” do que política ao mecanismo, ainda que as discussões tenham necessariamente uma dimensão política. Seguindo esta lógica, não será privilegiada a abordagem habitual do acompanhamento com base em relatórios de freqüência variável apresentado pelos Estados (muito burocrática e pouco eficiente), mas uma abordagem que se assemelhe mais ao que se pratica na OMC, com intuito de assegurar o acompanhamento do respeito das disciplinas comuns. No entanto, também é possível associar as duas abordagens. Há, contudo, um risco de mais trabalho, que acarretará o problema dos meios envolvidos na implementação do instrumento e no seu acompanhamento. É necessário, portanto, insistir no fato da necessidade de escolha. Ou queremos ter um efeito de propaganda, pouco importando a questão do acompanhamento, ou estamos preocupados em dar algumas possibilidades de eficácia ao instrumento e inscrevê-lo em dinâmica mais duradoura, sendo necessário, nesse caso, lançar bases sólidas.

\subsection{A composição do órgão}

Várias opções são possíveis: 
- entre uma composição plenária (preferível no espírito do instrumento e à imagem de o que se faz na OMC, mas com o problema dos meios) e uma composição restrita,

- entre uma composição exclusivamente de representantes de Estados (o que parece mais adequado) ou uma associação de peritos ou de personalidades qualificadas ou ainda da possibilidade de pedir o parecer de peritos, eventualmente precisando sobre quais questões - por exemplo, sobre aspectos econômicos. A associação de peritos pode colocar, muito rapidamente, o problema do lobbying.

- seja como for, seria bom talvez determinar as condições de capacidade para assegurar que os membros do Comitê têm alguns conhecimentos relativos aos aspectos econômicos das perguntas culturais.

\subsection{As atribuições do órgão}

Trata-se de um aspecto essencial. Seguem várias propostas que podem ser consideradas alternativa ou cumulativamente.

Em primeiro lugar, o Comitê de acompanhamento poderia ser considerado como o organismo encarregado de receber as notificações dos Estados, a título das obrigações processuais mencionadas na segunda parte do acordo (no que diz respeito aos esquemas de intervenção, às regulamentações internas, às regras de concorrência aplicáveis ao setor cultural, às subvenções). Podem-se diferenciar as obrigações e, por exemplo, em matéria de subvenções, pode-se acrescentar à obrigação de notificação dos sistemas de subvenções um relatório anual ou bienal de auto-avaliação. Os Estados comprometem-se a avaliar a eficácia das suas ações, incluindo em termos de não discriminação. Da mesma forma, poderia acontecer uma troca de conhecimentos e uma harmonização da abordagem dos instrumentos de intervenção.

Em segundo lugar, o Comitê de acompanhamento poderia ter a atribuição de debater, ou mesmo formular, recomendações relativas à conformidade com os objetivos do instrumento (instância de acordo): o interesse de tais procedimentos de informação e de controle pode ser de mostrar a "proporcionalidade" das intervenções. Pode-se inscrever a possibilidade de instaurar mecanismos de cooperação. Um Estado, por exemplo, que tem necessidade de cooperação técnica em matéria de direito da concorrência no ambito cultural poderia receber uma assistência técnica (o Comitê pode ser um lugar onde os Estados pedem 
ou propõem uma assistência técnica, a qual pode em seguida ser dispensada sobre uma base bilateral).

Em terceiro lugar, o Comitê de acompanhamento poderia ser considerado como um organismo que tem a capacidade de emitir “observações gerais” (à imagem do Comitê dos direitos humanos das Nações Unidas), o que está na origem de uma espécie de jurisprudência relativa ao instrumento em questão (isso permite conservar uma dinâmica e abordar questões não tratadas na negociação do instrumento - além disso, é mais leve e menos formal que um relatório anual ou bienal e permite orientar as perguntas essenciais ou mais atuais).

Em quarto lugar, poderia ser acrescentada a obrigação para um Estado que desejasse se empenhar em outros fóruns (por exemplo, compromissos de liberalização na OMC) de notificar as suas intenções aos seus parceiros através do Comitê. Isso envolveria compromissos com uma influência notável sobre a sua política cultural e a forma como seriam tratados os produtos e os serviços culturais originários de outros Estados partes. O procedimento poderia eventualmente ser confidencial (mas não é necessário alimentar paranóia). Pode-se acrescentar a possibilidade de recomendações do Comitê.

Em quinto lugar, pode-se vislumbrar que o Comitê seja um lugar de acordo para compromissos coletivos ou a determinação de posições comuns.

\section{A solução de controvérsias}

A questão da solução de controvérsias é delicada por vários aspectos. De um lado, existe uma resistência geral dos Estados a subscrever os modos regulatório para resolução dos litígios (o mecanismo da OMC é deste ponto de vista atípico). Esta é uma primeira razão pela qual é necessário dar uma atenção especial à dosagem do mecanismo que poderíamos propor, de modo que fosse considerado aceitável. Por outro lado, deve ser claro que, independentemente do mecanismo concebido e dos princípios eventualmente presentes no instrumento para assegurar a sua prioridade, ou mesmo afirmar a sua exclusividade para os litígios relativos ao instrumento, nunca se poderá impedir um ou vários Estados referidos de apresentar um destes litígios ao mecanismo de regulatório da OMC. Isso ocorre, pois o conflito comporta aspectos comerciais que entram no âmbito de aplicação do direito da OMC, com as conseqüências que resultam disso (tendo em conta a eficácia conhecida do mecanismo dessa organização). Nestas condições, e, na falta de poder se opor, a priori, e, de maneira 
definitiva, ao mecanismo OMC, a solução ótima parece ser a de propor um mecanismo que se afirme como concorrente, esperando que os riscos de conflito que resultam disso e o caráter indissociável que eles poderiam ter levem à conciliação. Nas linhas que seguem, explicar-se-á porque o mecanismo OMC não pode ser excluído, antes de vislumbrá-lo como meio concorrente. Trata-se de certa forma de acender um contra-fogo.

\subsection{A impossível evicção do mecanismo OMC}

O instrumento seria um ato externo ao direito da OMC, pois trata-se de dois espaços normativos distintos e que não são articulados entre si. O instrumento não poderia, assim, pretender produzir efeito jurídico algum no âmbito da OMC. Em outras palavras, ainda que fosse inscrito no instrumento um modo obrigatório de solução de controvérsias e um modo de saída obrigatória, ainda que fosse inscrita a obrigação para os Estados de considerálo como exclusivo, não se retiraria, contudo, o direito que tem, no Memorando de solução de controvérsias da OMC, de introduzir uma reclamação neste quadro, seja simultânea ou sucessivamente. Nenhum dos princípios permitiria opor-se a um grupo especial. Depois que o Órgão de apelação da OMC pronuncia-se não poderia efetivamente estar oposto, que tratasse da exceção de recursos paralelos, da proibição de fazer julgar duas vezes o mesmo caso (res judicata). Para que tais princípios sejam aplicáveis, seria necessário que houvesse um reconhecimento mútuo.

Pode-se acrescentar que continua possível sustentar que não se trata, em qualquer hipótese, de decidir exatamente o mesmo processo, uma vez que, evidentemente, não se trataria, nos dois procedimentos, de pedir a aplicação do mesmo direito.

O fato de um Estado recorrer ao mecanismo da OMC, quando ele tinha se comprometido a não o fazer no âmbito do instrumento, comprometeria a sua responsabilidade nos termos do instrumento e no que diz respeito aos Estados partes, mas não viciaria a sua queixa na OMC, nem o procedimento que se seguiria.

Isso não impede de inscrever efetivamente no instrumento o princípio da exclusividade do modo regulatório, o que pode ser, no mínimo, incitante, e o respeito pode ser um elemento de apreciação da boa fé. Mas não devemos superestimar os efeitos que poderia produzir tal princípio. Ele pode ser um elemento dentro de um conjunto mais amplo. 


\subsection{As propostas sobre a solução de controvérsias}

Estas propostas são de duas ordens: uma visa o ordenamento técnico de um mecanismo de solução de controvérsias, inspirando-se em diversos modelos existentes; outra visa o ordenamento do ambiente jurídico do mecanismo, a saber, princípios que seriam oportunos registrar no instrumento para facilitar a tarefa dos órgãos de solução de controvérsias.

Tendo em conta as resistências dos Estados a subscrever os mecanismos de solução de controvérsias que sejam muito restritivos, parece oportuno propor um mecanismo progressivo. Seria necessário, no entanto, que este mecanismo fosse concebido para ser bastante rápido, para não poder ser bloqueado e, por conseguinte, para assegurar uma saída efetiva (ainda que não seja impositiva porque se pode voltar para o acompanhamento) a fim de assegurar-lhe um mínimo de credibilidade. Dois sistemas são propostos como ilustrações das soluções imagináveis.

Numa primeira opção, de concepção clássica, pode-se pensar em uma fase inicial ligeiramente regulatória, que consiste em obrigação de negociação, acompanhada, no caso de malogro da possibilidade de recorrer aos serviços ou à mediação de uma terceira parte, de uma fase mais claramente regulatória, que retorne a um modo obrigatório de regulação do litígio.

A esse respeito, pode-se oferecer uma alternativa entre uma solução jurisdicional e uma pela conciliação. A opção pela solução jurisdicional, que poderia consistir quer numa arbitragem, quer numa decisão da Corte Tribunal internacional de justiça (CIJ), suporia uma aceitação prévia dos Estados referidos, sob forma de declaração facultativa, depositada quando da ratificação ou em qualquer momento ulterior escolhida pelo Estado envolvido. Esta declaração poderia visar apenas uma das duas vias jurisdicionais. As Partes de uma controvérsia, que não tivessem firmado tal compromisso (e um compromisso de mesmo alcance) e que não chegassem a um acordo sobre um outro procedimento de regulação como a possibilidade oferecida, seriam então reenviadas à conciliação. Pode-se também imaginar que a segunda fase seja mais claramente regulatória, mas isso poderia suscitar resistências.

O mecanismo sugerido assegura que um procedimento de solução de conflitos poderá acontecer. Para isso, as possibilidades de entrave devem ser eliminadas. É o caso quando, deixando ao mesmo tempo às partes a possibilidade de entender-se sobre um 
procedimento, existe, a título subsidiário, a possibilidade de ativar unilateralmente um procedimento, quer jurisdicional, se ambas as partes o aceitarem de antemão por uma declaração específica, quer de conciliação, se as partes que aceitaram adiram à Convenção (com exceção da questão das reservas). Seria necessário também elaborar dispositivos adequados, para que a desistência de uma das Partes no procedimento, seja para proceder às designações que lhe incumbem eventualmente, seja para alegar os seus argumentos, não a impeça de chegar ao seu final. Enfim, o sistema deveria ser concebido de modo que o processo de regulação fosse o mais rápido possível. Se a negociação não for fechada nos prazos, os modos obrigatórios, com exceção do recurso a CIJ, podem ser, o que garantirão uma solução ou uma proposta de solução em um prazo razoável.

Uma segunda opção poderia ser um mecanismo no qual a estrutura e o desenvolvimento aproximar-se-iam dos mecanismos de solução de controvérsias da OMC. Lá também, a idéia de progressividade estaria de qualquer maneira presente, mas a segunda fase estaria limitada a oferecer um mecanismo de tipo arbitral, mesmo com a previsão de que as partes podem dispor diferentemente. Assim, inicialmente, um ou vários Estados partes que consideraria(m) que uma medida de um dos seus parceiros não respeita o instrumento poderia(m) pedir consultas a ele. Estas consultas poderiam ser fechadas em prazos que, no final, no caso de malogro, uma ou as partes em litígio poderia(m) pedir a constituição de um Comitê de peritos, a menos que elas não cheguem a um acordo de recorrer a outro modo de regulamento. O Comitê de peritos teria que decidir, em prazo determinado, no fim de um procedimento contraditório. Poder-se-ia prever que ele fixe, ao mesmo tempo, um prazo de adequação, na hipótese em que se constate violação do instrumento, controle da eficácia da execução e sanções, no caso de não-execução.

Além do mecanismo propriamente dito, pode-se pensar em incorporar, no seu ambiente normativo, princípios suscetíveis de facilitar a tarefa dos órgãos de regulação. Tratar-se-iam, principalmente, de princípios relativos à articulação do instrumento com o resto do direito internacional, incluindo, portanto, o direito da OMC. Esses princípios valeriam certamente apenas na ordem do instrumento, mas podem ajudar a estabelecer a sua influência. Poder-se-ia, assim, mencionar, por exemplo, no preâmbulo, que "os acordos sobre o comércio e a cultura deveriam apoiar-se mutuamente com o propósito do respeito à diversidade cultural na sua dupla dimensão de proteção das culturas e da abertura às outras 
culturas”. Nesse mesmo sentido, o instrumento, não devendo ser interpretado como modificação dos direitos e obrigações de uma Parte em virtude de outros acordos internacionais, não deveria ser considerado como subordinado a outros acordos internacionais.

Tal regra de interpretação teria por objetivo evitar o jogo de qualquer regra de prioridade, como comporta o direito internacional (particularmente, no artigo 30 da Convenção de Viena sobre o direito dos tratados). Dado que o instrumento não seria suposto alterar os direitos e obrigações convencionais preexistentes das suas Partes, não teria a reclamar-se nem da regra Lex specialis, nem da regra Lex posterior cuja aptidão a atuar não foi verificada. Da mesma forma, há uma presunção de compatibilidade com o direito da OMC (entre outras). Em seguida, indicando que este princípio de não-contradição não é um princípio de subordinação, tratar-se-ia de exprimir que o instrumento não tem de ser afastado, quando outro acordo internacional é aplicável. Esta precisão é importante: não alterando nada, o instrumento poderia, no entanto, acrescentar e, nessa medida, não deveria ser ignorado (o que poderia visar, contudo apenas as relações entre as Partes). Em outras palavras, tratar-se-ia de orientar para uma aplicação cumulativa, o que apenas confirmaria a menção necessária a um apoio mútuo.

\section{As repercussões do novo instrumento}

O novo instrumento agirá primeiro e, sobretudo, como um quadro de referência e um fórum de acordo para todos os Estados que consideram a manutenção da diversidade das expressões culturais, e, por meio dessa, a preservação da diversidade cultural própria como elementos essenciais para a realização de uma mundialização com cara humana. Como quadro de referência, oferecerá um conjunto de princípios e normas destinados a enquadrar a intervenção dos Estados-Membros no domínio cultural, pela mesma concepção da diversidade cultural centrada, ao mesmo tempo, sobre a preservação das culturas existentes e sobre a abertura as outras culturas. Com a adesão de um número crescente de Estados a esse quadro de referência, assistiremos então a instauração, no domínio cultural, de um novo regime jurídico fundado sobre uma visão cultural da troca, uma visão em que o desenvolvimento deste acompanha o desenvolvimento das culturas, mas não se sobrepõe a esses últimos. Esse quadro de referência, além de guiar a ação dos Estados-Membros na esfera doméstica, poderá 
igualmente servir-lhes de posição comum nas suas negociações internacionais. Como fórum de acordo, o novo instrumento oferecerá a possibilidade de ajudar os Estados-Membros que encontram dificuldades no cumprimento dos seus compromissos, facilitará, se for o caso, a solução de controvérsias entre eles e contribuirá para a tomada de posições comuns sobre qualquer pergunta relacionada à preservação da diversidade cultural. Longe de ser um instrumento estático e protecionista, revelar-se-á ao contrário um instrumento de desenvolvimento das culturas e dos intercâmbios culturais.

\section{Parte III. Identificação das soluções jurídicas que garantem uma articulação satisfatória deste instrumento internacional com a OMC}

A principal dificuldade de um instrumento internacional sobre a diversidade cultural negociado fora da OMC é a sua relação com o regime normativo existente nessa organização. Nesse âmbito, é importante esclarecer o que continua a ser possível e o que já não mais. A margem da manobra em relação à OMC é, ao mesmo tempo, ampla e limitada. Ela é ampla, pois, até o momento, poucos Estados firmaram compromisso de liberalização em matéria de serviços culturais, e não estamos, teoricamente, obrigados a nada enquanto não firmamos um compromisso. Na realidade, a possibilidade de atuação é limitada por uma pluralidade de fatores, que se usura para explicar os meios de ação que podemos ter e as vias imaginadas para o instrumento projetado sobre a diversidade cultural.

É importante lembrar que, atualmente, os produtos e os serviços culturais não são, de modo algum, excluídos, em princípio, do âmbito de aplicação do direito da OMC. No que diz respeito, especialmente, aos serviços sobre os quais se concentram os desafios (devido aos serviços audiovisuais), se não forem objeto de negociações específicas para fins de liberalização, isso resulta apenas de uma decisão política em vistas das circunstâncias. Podese, por conseguinte, a todo o momento, ter o inicio de negociação. Aliás, existem várias propostas neste sentido (mesmo se, como foi dito, poucos Estados tem até o momento firmado compromissos). Nesta perspectiva, o instrumento constituiria um ponto de apoio para os Estados partes a fim de justificar uma recusa de firmar um compromisso cultural ou audiovisual ou de coordenar as suas posições na matéria ou de reagir a eventuais tentativas de desenvolvimento normativo sobre a diversidade cultural na OMC. 
No que diz respeito à articulação entre o instrumento sobre a diversidade cultural e o direito da OMC, é importante recordar primeiro que o instrumento não poderia produzir outro resultado a não ser um efeito indireto sobre o direito da OMC antes de abordar várias questões mais específicas de articulação (essencialmente a respeito dos diferentes meios de intervenção dos Estados).

\section{$1 \mathrm{O}$ efeito indireto}

De maneira geral, não se pode esperar do instrumento outro efeito senão indireto. Esse efeito pode ser procurado em relação ao direito existente (mas as observações feitas a este propósito valerão também para qualquer direito futuro). Pode ser procurado, igualmente, nas negociações vindouras.

1.1 Em relação ao direito existente, o instrumento poderia produzir, eventualmente, efeito apenas sobre a sua interpretação.

E ainda, esse efeito é longe de ser assegurado, mas pode-se, no entanto, tentar consolidar, no máximo, as bases. Daí a concepção e a estrutura retida para o instrumento. Esse, deliberadamente sendo formulado também em termos “culturais”, quer fazer eco aos modos de raciocínio em vigor no direito da OMC.

Como não é elaborado na OMC, não se pode esperar que atinja ao conjunto dos Estados-Membros da OMC e que a sua eventual conclusão e entrada em vigor serão, em qualquer hipótese, posteriores as dos Acordos de Marraqueche, uma vez que o instrumento é inapto a questionar ou alterar o direito da OMC existente. Assim, um Estado não poderia fazer uso do instrumento para justificar o descumprimento de um das suas obrigações nos termos do direito da OMC. Uma mudança das obrigações pode vir apenas do interior. Em outras palavras, não se pode esperar impor uma “exceção” ou uma “especificidade” cultural do exterior. Qualquer mudança deste tipo pode vir apenas de negociações internas na OMC. A este respeito, deve-se lembrar que o "trem" de uma verdadeira exceção cultural foi perdido em 1994. As possibilidades que tal exceção possa ser re-introduzida como exceção global são infinitesimais, para não dizer nulas. Seria necessário, na verdade, rever vários acordos contidos na Carta da OMC e, para isso, estabelecer a concordância no conjunto dos membros 
da organização. Pode-se considerar, com uma certeza razoável, que tal acordo está fora de alcance.

Isso não significa que nada possa ser feito dentro do direito da OMC (cf. infra). Isso também não significa que o direito externo à OMC não possa produzir efeito.

Em relação ao direito existente (que seja hoje ou posteriormente), uma confrontação eventual entre uma ou várias obrigações, no abrigo da OMC, e uma posição nacional fundada sobre o instrumento por-se-ia, essencialmente, no âmbito da solução de controvérsias. Porém, o Memorando sobre a solução de controvérsias prevê que o direito da OMC deve ser interpretado "em conformidade com as regras usuais de interpretação do direito internacional público" (artigos 3.2). Por isso, os grupos especiais e o Órgão de Apelação referem-se às regras, aos princípios e aos métodos de interpretação mencionados nos artigos 31 e 32 da Convenção de Viena sobre o direito dos tratados, de 23 de Maio de 1969, ainda que esta referência não seja exaustiva, uma vez que se recorre, igualmente, a métodos como ao do efeito útil como necessidade. O leque é, portanto, bastante amplo. Acrescenta-se, ainda, que, após o seu primeiro relatório (caso da gasolina ${ }^{24}$ ), o Órgão de Apelação indicou que o direito da OMC não estava “isolado clinicamente” do resto do direito internacional. Em outras palavras, o direito da OMC pode e deve ser interpretado em face dos princípios de direito internacional de origem externa. A possibilidade de utilizar o princípio de precaução foi assim explorada no assunto da carne com hormônios, ainda que, nesse caso, esse princípio não tenha sido considerado como suficientemente consolidado para constituir a referência que desejavam os defensores ${ }^{25}$.

Os órgãos de solução de controvérsias não hesitam em referir-se a princípios e regras externos. As referências à jurisprudência da Corte Internacional de Justiça são numerosas. O caso dos camarões foi, igualmente, a ocasião para referências a vários instrumentos de direito internacional do meio ambiente, com intuito de interpretar o artigo XX: g) do GATT. Observaremos a esse respeito que o Órgão de Apelação visou, igualmente, instrumentos regulatórios (sem se preocupar em saber se os Estados partes na controvérsia foram vinculados por eles), em vez dos instrumentos não-obrigatórios (como a Declaração do

\footnotetext{
${ }^{24}$ Estados Unidos - Normas relativas à gasolina nova e antiga fórmulas (WT/DS2/AB/R). Relatório de chamada de 29 de Abril de 1996 adoptado pelo O.R.D. o 20 de Maio de 1996

${ }^{25}$ Comunidades Européias - Medidas relativas às carnes e os produtos cárneos (hormonas) (WT/DS26/AB/R; WT/DS48/AB/R). Relatório de chamada comum aos dois negócios introduzidos respectivamente pelo Canadá e os Estados Unidos, postos em circulação o 16 de Janeiro de 1998 e adoptados o 13 de Fevereiro de 1998
} 
$\mathrm{Rio}^{26}$ ) e, de maneira mais geral, a margem de manobra em matéria de interpretação do espaço para receptividade quanto à sensibilidade das questões tratadas. $\mathrm{O}$ caso do amianto mostrou isso em relação às preocupações com a saúde. E essa receptividade tem possibilidades de ser tão maior, a ponto de a sensibilidade manifestar-se-á de maneira coletiva.

Tendo em conta todos esses elementos, a situação parece bastante aberta. Um instrumento "cultural" que reflete certo consenso poderia ser de natureza a influenciar a diligência interpretativa dos órgãos de solução de controvérsias da OMC, principalmente porque isso permitiria mostrar que a posição do Estado em questão não é necessariamente isolada (sob reserva dos dados específicos do caso e a adequação da posição do Estado referido com os princípios seguidos no âmbito do instrumento). Sem dúvida, a analogia com o que se passou em relação ao direito do meio ambiente não deve ser levada muito mais longe do que isso. É necessário na verdade levar em conta que existe, no caso do direito ambiental, uma menção no Preâmbulo da Carta da OMC que serviu de alavanca. As questões culturais não beneficiam de tal situação, à exceção de o que poderia ser obtido em negociações ulteriores (cf. infra) ou ainda em tentativas de se fazer eco à referência que traz o preâmbulo do Acordo geral sobre o comércio dos serviços “aos objetivos de política nacional”, qualificando como tal a diversidade cultural no instrumento (cf. supra).

No mais, o Órgão de Apelação não parece, até agora, ter-se mostrado muito receptivo aos argumentos “culturais” (surgidos no caso dos periódicos ou nos casos coreanos das bebidas alcoólicas ou do boi congelado). Isso não deve, contudo, ser considerado como plenamente significativo. As vantagens de um instrumento para ser levado em consideração, ainda que necessariamente de maneira indireta, viriam do seu equilíbrio interno e da forma como responde a várias preocupações dos órgãos de solução de controvérsias.

As preocupações desses órgãos estão sempre voltadas para encontrar, atrás de medidas que buscam um objetivo legítimo (o que a diversidade cultural pretende ser), as tentações ou os desvios protecionistas, daí o interesse:

- de insistir bem na dupla dimensão da diversidade cultural (a proteção das culturas nacionais ou infra-nacionais, mas também a abertura às outras culturas e a não discriminação);

\footnotetext{
26 Estados Unidos - Proibição à importação de certos camarões e certos produtos feitos com camarões (WT/DS58/AB/R). Relatório de chamada de 12 de Outubro de 1998, adotado o 6 de Novembro de 1998
} 
- de assegurar uma grande transparência relativa aos diferentes mecanismos de intervenção e de proteção (para mostrar que a diversidade cultural não é um pretexto para “mascarar” uma política exclusivamente protecionista);

- de mostrar os diferentes mecanismos de intervenção estatais, senão negociados, pelo menos objetos de acordo (nos casos da gasolina e dos camarões, o Órgão de apelação acusou principalmente nos Estados Unidos uma diligência totalmente unilateral), e de um acompanhamento (há a preocupação de verificar a sua adequação, ou mesmo, a sua proporcionalidade aos objetivos perseguidos, o que pode ser um forte indicio de boa fé).

Enfim, um último estímulo a levar em conta no instrumento, ainda que indiretamente, pode vir da “concorrência” dos mecanismos de solução de controvérsias, dado que poderiam ter que conhecer problemáticas, ou casos, estreitamente ligados. Sem dúvida, o seu funcionamento continuará a ser autônomo (cf. supra), mas a realização de uma concorrência conflituosa apresentaria riscos para os dois mecanismos e os dois sistemas. Causadora de tensões, essa competição traria, simultaneamente, problemas de credibilidade e de legitimidade. Os riscos, proporcionalmente ao grau de adesão que receberia o instrumento, poderiam existir em dois níveis:

- O do caso em questão, já que um Estado poderia ter uma medida validada, ou mesmo exigida, numa ordem, mas ser condenada na outra. Seria então obrigado a ficar em falta com uma ordem para se adequar à outra, podendo a situação ser agravada pela possibilidade de constrangimentos na execução. A situação seria juridicamente indissolúvel e, potencialmente, geradora de uma tensão duradoura.

- O do caso do sistema. Não é necessário insistir no efeito desestabilizador de decisões contraditórias, em função, certamente, do sucesso do instrumento (daí o interesse de prever um limite de entrada em vigor suficiente). Uma comparação adequada oferece-se por meio do caso do peixe-espada ${ }^{27}$, que opôs União Européia e Chile e no qual interagia o direito do mar oriundo da Convenção de Montego Bay e o direito da OMC. Se o conflito não foi até

\footnotetext{
${ }^{27}$ WT/DS193/1 no âmbito da OMC. A Comunidade Européia tinha apresentado em Abril de 2000 um pedido de consulta relativo a uma medida chilena que proíbe desembarcar peixes-espada nos portos chilenos. Considerava que o Chile fazia obstáculo de transporte em trânsito dos peixes-espada nos seus portos em violação dos artigos V e XI do GATT. Em paralelo com esta medida, o Chile tinha adotado igualmente medidas de conservação que visavam limitar a pesca do peixe-espada. Em resposta à queixa europeia no âmbito da OMC, o Chile recorreu ao sistema da Convenção sobre o direito do mar de 1982 e procurou atrair a Comunidade Européia para o Tribunal internacional do direito do mar.
} 
o final e se as partes chegaram a um acordo ${ }^{28}$, foi, sem dúvida, porque todos compreenderam que não havia interesse em concretizar tão precisamente a perspectiva de decisões potencialmente contraditórias, ainda que o conflito continuasse a ser formalmente indireto. Além disso, também não seria do interesse dos órgãos chamados a regular as controvérsias de alimentar tais tensões, que poderiam ocasionar o risco de colocar em questão não somente a sua credibilidade, mas também a sua legitimidade. O argumento, de ser sistemático, e não jurídico, não é, ainda assim, negligenciável. Reconhece-se a vulnerabilidade dos órgãos da OMC nesse âmbito, e a rapidez com a qual são taxados de não ter nenhuma preocupação com as questões não comerciais, apesar dos esforços de abertura que mostram, entre outros, os casos dos camarões ${ }^{29}$, da carne coreana $^{30}$ ou do amianto ${ }^{31}$. O risco envolveria também, certamente, os órgãos chamados a intervir nos termos do instrumento. Isso resultaria num forte estímulo da consideração da reciprocidade.

\subsection{Em relação às negociações futuras}

Em relação às negociações futuras, o instrumento não pode, evidentemente, pretender impedir os desdobramentos no âmbito da OMC. Ele pode apenas contribuir para orientá-los ou para contê-los, o que é, principalmente, uma função do seu grau de sucesso, mas não unicamente.

A capacidade de influência pode passar pela instauração de um mecanismo de coordenação de posições nas negociações na OMC (por exemplo, qualquer Estado parte do instrumento que queira apresentar propostas ou firmar compromissos deveria, antes, informar seus parceiros e recolher suas observações; ou ainda poder-se-ia pensar num mecanismo de acordo para coordenar as posições nas negociações). Como houve com o grupo de Cairns na

\footnotetext{
${ }^{28}$ Inicialmente, as Partes acordaram em apresentar a controvérsia a um tribunal arbitral nas condições previstas pela Convenção de Montego Bay, antes de chegar a um acordo amigável. Mas, paralelamente, um grupo especial tinha sido estabelecido pelo ORD (em Dezembro de 2000), procedimento que foi abandonado igualmente na sequência do acordo amigável.

29 Organe d'appel - 12 octobre 1998 - WT/DS58 - Prohibition à l'importation de certaines crevettes et de certains produits à base de crevettes (Inde, Malaisie, Pakistan et Thaïlande c. États-Unis). V. H. Ruiz Fabri, « Chronique du règlement des différends de l’O.M.C.», J.D.I., 1999/2, p. 496.

30 Organe d'appel. - 11 décembre 2000. - WT/DS161/AB/R et WT/DS169/AB/R. - Mesures affectant les importations de viande de bœuf fraîche, réfrigérée et congelée (Australie et États-Unis c. Corée). V. H. Ruiz Fabri, « Chronique du règlement des différends de l’O.M.C.», J.D.I., 2001/3, p. 929.

31 Organe d'appel. - 12 mars 2001. - WT/DS135/AB/R. - Mesures affectant l'amiante et les produits en contenant (Canada c. Communautés européennes). V. H. Ruiz Fabri, «Chronique du règlement des différends de l’O.M.C.», J.D.I., 2001/3, p. 948.
} 
questão agrícola, pode-se imaginar um grupo de Estados federados por um instrumento em matéria cultural.

O instrumento poderia servir de referência: a opção por formulações que, mesmo sendo “culturais”, façam eco aos conceitos, ao modo de pensar e as orientações em vigor na OMC pode facilitar este papel. A introdução no direito da OMC de uma referência, mesmo que preambular, à legitimidade da preocupação com a manutenção da diversidade cultural poderia ser muito útil (principalmente para servir de alavanca de eventuais referências a instrumentos externos no direito da OMC para a interpretação de dispositivos deste).

Poderia ser útil, nesse sentido, que o instrumento se referisse ao compromisso dos membros "ter em mente a necessidade de apoiar e promover a diversidade cultural nas outras instâncias internacionais onde poderiam ser convidados a firmar compromissos suscetíveis de comprometer a eficácia do instrumento", utilizando a formulação da Declaração do Conselho da Europa sobre a diversidade cultural.

\section{Questões específicas de articulação}

A questão da articulação entre o direito da OMC e as preocupações que traduziriam o instrumento sobre a diversidade cultural pode ser posta em vários níveis. Existe,

obviamente, o nível dos compromissos. É, sem dúvida, essencial, pelo menos num primeiro momento, que nenhum compromisso de liberalização seja tomado no âmbito da OMC pelo maior número possível de Estados (a preparação e a conclusão do instrumento sendo um argumento forte para incitar tal posição de espera comum justificando-a).

Igualmente necessário é considerar que, ainda que nenhum compromisso seja tomado, negociações sobre outras perguntas podem ter repercussões sobre o controle dos meios de ação em prol da diversidade cultural. Isto é, particularmente, verdadeiro para tudo o que se refere às disciplinas horizontais ou transversais como as regulamentações internas ou as subvenções. Importante insistir no fato de que uma situação de statu quo não é uma situação imóvel nem suficiente para não firmar compromisso. Se a situação não for consolidada, degradar-se-á, ou seja, evoluir-se-á para um sentido não necessariamente favorável às preocupações que justificam a elaboração do presente instrumento. Enfim, parece essencial poder incorporar no direito da OMC ecos às preocupações traduzidas pelo instrumento.

PRISMAS: Dir., Pol.Pub. e Mundial., Brasília, v.4, n, 1, p 215-272, jan/jul. 2007 
As linhas que se seguem recordam que:

- o que é autorizado ou não é mais,

- o que está discussão e como se pode conciliar.

\subsection{O que é autorizado ou não é mais}

Na ausência de qualquer compromisso, a margem de manobra parece muito ampla. É necessário, contudo, prestar atenção a três elementos:

- O acordo sobre serviços tem sido objeto, até o momento, de apenas algumas poucas aplicações contenciosas. Resta a fazer no que diz respeito a sua interpretação. A experiência mostra, no entanto, que os dispositivos não são, necessariamente, interpretados exatamente como os seus negociadores os conceberam. Além disso, a jurisprudência é completamente orientada para uma aplicação cumulativa e sobreposta de diferentes dispositivos contidas nos acordos da OMC e uma interpretação das regras umas em relação as outras, incluindo essas regras mesmo quando figuram em acordos diferentes. Pode resultar num fenômeno de “contaminação das restrições”, ou seja, uma regra interpretada em sentido mais restritivo à luz de outras disposições de outros domínios. Pode-se, por exemplo, pensar no domínio das subvenções que será mais ou menos, a curto prazo, negociado no setor dos serviços, enquanto que já existe um aparelho normativo específico relativo às subvenções em matéria de bens.

- Além disso, certas disciplinas ou certos princípios do Acordo sobre serviços podem atuar independentemente de qualquer compromisso. Isso se tornará necessariamente atual no fim das isenções. É importante, uma vez mais, insistir no fato dos produtos e dos serviços culturais não se beneficiarem de nenhum regime de exceção global.

- As negociações sobre certas questões, em especial sobre as disciplinas horizontais ou transversais, terão, necessariamente, repercussões sobre a situação dos serviços culturais, ainda que persistam nas posições de não-compromisso.

\subsection{O que está em discussão e como conciliar}


Trata-se de assinalar as questões que ainda não foram reguladas, mas também as hipóteses nas quais seriam desejáveis tentar introduzir no direito da OMC dispositivos ou precisões que fazem eco às preocupações que regem a elaboração do instrumento.

- Inicialmente, é importante saber quais são as perspectivas que envolvem as isenções. Essas normalmente não deveriam durar mais de dez anos, o que significa que as introduzidas em 1995 deveriam logicamente desaparecer a partir de 2005. A questão de uma eventual prolongação deveria eventualmente ser apreciada.

- Seria necessário refletir sobre a maneira adequada de formular os compromissos ou a ausência de compromissos: a idéia seria fazer do instrumento uma referência para legitimar uma ausência de acordo ou uma não-consolidação de tudo o que não estaria em acordo com os seus objetivos. Dado que o instrumento não impõe nível identificado de proteção, o seu alcance real residiria, sobretudo, num efeito de anúncio e na introdução de uma referência que pode servir para a interpretação dos compromissos. Tratarse-ia de fazer valer a idéia de que uma ação em acordo com o instrumento respeita os imperativos em matéria de transparência e proporcionalidade, noções que têm um forte eco no direito da OMC. Poderia ser um meio de confirmar, ainda que não se firme compromisso, que se esta agindo, entretanto de maneira transparente e proporcionada. Trata-se de dar uma espécie de garantia de que não esta agindo aleatoriamente de acordo com seus interesses, mantendo, ao mesmo tempo, o direito de agir.

- Muita atenção é necessária em relação às negociações relativas às disciplinas horizontais, em especial no que diz respeito às regulamentações internas e às subvenções. Em ambos os casos, seria necessário examinar em que medida seria possível negociar a introdução de uma cláusula de exceção ligada aos “objetivos de política nacional”, ou mesmo, mais voltada a medidas tomadas em conformidade com o instrumento, mesmo que não o visasse expressamente. É preciso ecoar seus objetivos e seus métodos, respeitando também o esquema do direito da OMC em matéria de exceção. Este esquema requer que as medidas obedeçam a um objetivo legítimo, mas também que sejam transparentes e proporcionais. Em outras palavras, a diversidade cultural, tal como concebida no âmbito do instrumento (i.e. com a sua dupla dimensão - $c f$. supra), deveria ser considerado como um objetivo legitimo, o que justificaria as medidas tomadas escaparem às disciplinas comuns, com a condição de que sejam transparentes e proporcionais. São essas tantas exigências que colocam o instrumento 
tal como é concebido no presente relatório (cf. supra). Tratar-se-ia de criar uma espécie de efeito espelho.

Em matéria de subvenções, se se instauram disciplinas comuns, conduz-se à uma lógica de definição progressiva, de determinação de critérios e de eliminação progressiva. Mas pode-se tentar talvez testar a introdução de uma "caixa verde” que recobriria as subvenções em nome da diversidade cultural ou pensar em negociar um regime equivalente à Medida global de apoio em matéria agrícola, mas sem desmantelamento no final. Seria necessário evitar chegar a uma definição ou uma lista das medidas autorizadas, o que poderia revelar-se restritivo demais e pouco adaptável. Preferir-se-ia uma fórmula na qual se confere, antes de tudo, sobre o modelo já indicado, garantias de transparência e de proporcionalidade (sempre em relação à dupla dimensão da diversidade cultural, o que também é uma maneira de dar garantias sobre a abertura aos outros).

Os propósitos precedentes à articulação do instrumento à OMC, pode-se alegar, levantam uma questão que ressalta de um horizonte temporal distinto do processo de elaboração do instrumento como tal, ou seja, a elaboração do instrumento podendo ser feita fora de qualquer consideração da OMC. Em teoria, isso não é falso, especialmente porque o instrumento tem uma vocação primeira e, sobretudo, cultural, enquanto que a OMC tem uma vocação exclusivamente comercial, mas o instrumento teria também por objetivo assegurar a capacidade de intervenção dos Estados no domínio cultural perante a OMC. A sua elaboração dificilmente pode ser feita sem levar em consideração as exigências Dessa organização. Isso não significa que o instrumento deva ceder perante a OMC, mas, na medida em que, a possibilidade de conflitos não pode ser eliminada, não é proibido procurar estabelecer pontes suscetíveis de facilitar o seu regulamento numa perspectiva aceitável de um ponto de vista cultural. Pode-se interrogar, também, se é possível distinguir entre o que é da competência dos conteúdos do instrumento, que poderiam eventualmente servir de conexão ao direito da OMC, e o que revela, antes de tudo, estratégias que visam esta ligação. Tal distinção é possível, mas o conteúdo do instrumento implica, de certa maneira, escolhas estratégicas relativas aos meios de atingir os objetivos fixados. Dado que estes objetivos incluem a preservação das capacidades de intervenção dos Estados no domínio cultural, a questão do atrelamento é levantada. 


\section{ANEXO 1}

O desequilíbrio das trocas no domínio do audiovisual: a situação na Europa

TELEVISÃO

\section{Europa}

Origem geográfica da ficção televisiva programada pelos principais canais (amostra semanal do 12 ao 18 de Março de 2000)

\begin{tabular}{|c|c|c|c|c|c|}
\hline \multirow{3}{*}{$\begin{array}{l} \\
\text { Reino } \\
\text { Unido }\end{array}$} & & NACIONAL & AMERICANA & EUROPEIA & OUTROS \\
\hline & dia inteiro & $47 \%$ & $43 \%$ & $0 \%$ & $10 \%$ \\
\hline & $\begin{array}{l}\text { somente horas de } \\
\text { grande audiência }\end{array}$ & $51 \%$ & $49 \%$ & $0 \%$ & $0 \%$ \\
\hline \multirow[t]{2}{*}{ Alemanha } & dia inteiro & $36 \%$ & $57 \%$ & $5 \%$ & $2 \%$ \\
\hline & $\begin{array}{l}\text { somente horas de } \\
\text { grande audiência }\end{array}$ & $56 \%$ & $44 \%$ & $0 \%$ & $0 \%$ \\
\hline \multirow[t]{2}{*}{ França } & dia inteiro & $25 \%$ & $56 \%$ & $15 \%$ & $5 \%$ \\
\hline & $\begin{array}{l}\text { somente horas de } \\
\text { grande audiência }\end{array}$ & $75 \%$ & $25 \%$ & $0 \%$ & $0 \%$ \\
\hline \multirow[t]{2}{*}{ Italia } & dia inteiro & $19 \%$ & $64 \%$ & $4 \%$ & $13 \%$ \\
\hline & $\begin{array}{l}\text { somente horas de } \\
\text { grande audiência }\end{array}$ & $43 \%$ & $51 \%$ & $6 \%$ & $0 \%$ \\
\hline \multirow[t]{2}{*}{ Espanha } & dia inteiro & $20 \%$ & $56 \%$ & $7 \%$ & $17 \%$ \\
\hline & $\begin{array}{l}\text { somente horas de } \\
\text { grande audiência }\end{array}$ & $51 \%$ & $37 \%$ & $12 \%$ & $0 \%$ \\
\hline
\end{tabular}

Fonte: EUROFICTION Dados do Observatório europeu do audiovisual http://www.obs.coe.int/about/oea/pr/pr_eurofiction_bis.html.fr

\section{FILMES}

União Européia

Fatias do mercado das entradas no mercado da União Européia (1996-2000)

\section{FRANÇA}

Fatias do mercado segundo a nacionalidade dos filmes (\%)

\begin{tabular}{c|c|c|c|c|l}
\hline & FILMES & FILMES & FILMES & EUROPEUS \\
FRANCESES & AMÉRICANOS & $\begin{array}{c}\text { OUTROS } \\
\text { FRANÇA) }\end{array}$ & FILMES & TOTAL \\
\hline
\end{tabular}




\begin{tabular}{c|c|c|c|c|c}
1991 & 30,6 & 58,0 & 10,0 & 1,4 & 100,0 \\
\hline 1992 & 35,0 & 58,2 & 4,7 & 2,2 & 100,0 \\
\hline 1993 & 35,1 & 57,1 & 4,4 & 3,4 & 100,0 \\
\hline 1994 & 28,3 & 60,9 & 8,7 & 2,0 & 100,0 \\
\hline 1995 & 35,2 & 53,9 & 8,4 & 2,4 & 100,0 \\
\hline 1996 & 37,5 & 54,3 & 6,2 & 2,0 & 100,0 \\
\hline 1997 & 34,5 & 52,2 & 10,0 & 3,3 & 100,0 \\
\hline 1998 & 27,6 & 63,2 & 7,6 & 1,6 & 100,0 \\
\hline 1999 & 32,4 & 53,9 & 11,1 & 2,6 & 100,0 \\
\hline $2000^{*}$ & 28,5 & 62,9 & 6,0 & 2,6 & 100,0 \\
\hline
\end{tabular}

*Dados provisórios Fonte: Centro nacional da cinematografia, http://www.cnc.fr/d_stat/fr_d.

\section{ANEXO}

O desequilíbrio das trocas no domínio do audiovisual: a Austrália e o Canadá

\section{AUSTRÁLIA}

Número de filmes australianos e estrangeiros projetados nos cinemas australianos,

1984-2000

\begin{tabular}{|c|c|c|c|c|c|c|c|c|c|c|}
\hline & \multirow[b]{2}{*}{ Axersears } & \multirow[b]{2}{*}{ Ne } & \multirow[b]{2}{*}{$\sin$} & \multicolumn{3}{|c|}{ Exouosen } & \multicolumn{2}{|c|}{ NootrI Akimena } & \multirow[b]{2}{*}{$\begin{array}{l}\text { Aormas } \\
\text { soss }\end{array}$} & \multirow[b]{2}{*}{ Toral. } \\
\hline & & & & Fruarton & F.U. & 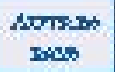 & Cartarat & $\begin{array}{l}\text { ETSTE- } \\
\text { urto }\end{array}$ & & \\
\hline 1984 & 25 & 1 & 0 & 9 & 22 & 12 & 4 & 146 & 4 & 223 \\
\hline 1985 & 17 & - & 1 & 4 & 25 & 5 & 4 & 130 & 2 & 104 \\
\hline 1986 & $\infty$ & 2 & 6 & 8 & 25 & $\mathbf{0}$ & - & 155 & 3 & 239 \\
\hline 1987 & 31 & 1 & 7 & 12 & 18 & 14 & 5 & 108 & 3 & 250 \\
\hline 1988 & $\infty$ & 2 & 6 & $\mathbf{0}$ & 31 & 22 & 3 & 107 & 4 & 281 \\
\hline 1989 & $\infty$ & - & 13 & 14 & 35 & 10 & 3 & 103 & 5 & 201 \\
\hline 1990 & 22 & 3 & 7 & 26 & 20 & 14 & 6 & 153 & 1 & 252 \\
\hline 1991 & 27 & 1 & 8 & 16 & 21 & 16 & 3 & 140 & 4 & 240 \\
\hline 1992 & $\infty$ & 1 & 5 & 9 & 28 & 15 & 6 & 135 & 1 & 229 \\
\hline 1993 & 22 & 3 & 8 & 14 & 13 & 17 & 5 & 172 & 5 & 250 \\
\hline 1994 & 25 & 2 & 12 & 17 & 22 & 13 & 6 & 153 & 1 & 252 \\
\hline 1995 & 14 & 1 & 6 & 17 & 23 & 13 & 3 & 171 & 5 & 253 \\
\hline 1996 & 25 & 1 & 9 & 12 & 25 & $\mathbf{p}$ & 3 & 100 & 6 & 281 \\
\hline 1997 & $\infty$ & 2 & 8 & 17 & 21 & 13 & 8 & 184 & 2 & 285 \\
\hline 1998 & 20 & - & 5 & 12 & 20 & 5 & 3 & 180 & 10 & 273 \\
\hline 1999 & 24 & 3 & 3 & 5 & 28 & 11 & 5 & 174 & 2 & 255 \\
\hline 2000 & 22 & - & 8 & 12 & 29 & 6 & 3 & 107 & 3 & 250 \\
\hline \multicolumn{11}{|c|}{ Fo ureertage } \\
\hline 2000 & $9 \%$ & - & $3 \%$ & $5 \%$ & $12 \#$ & $2 \eta$ & $1 \%$ & $\sigma \%$ & $1 \%$ & \\
\hline moyerme & $11 \%$ & $1 \%$ & $3 \%$ & $6 \%$ & 11 & $6 \%$ & $2 \%$ & $73 \%$ & $2 \geqslant$ & \\
\hline
\end{tabular}

Fonte: MPDAA

\section{CANADÁ}


Distribuição (MM\$ e \%) das receitas de produções audiovisuais * de acordo com a mídia principal e a nacionalidade das produções, 1998-1999

\begin{tabular}{l|c|c|c}
\hline & PRODUÇÕES & $\begin{array}{c}\text { PRODUÇÕES } \\
\text { NÃO } \\
\text { CANADENSES }\end{array}$ & TOTAL \\
\hline $\begin{array}{l}\text { Distribuição } \\
\text { interna } \\
\text { (mercado } \\
\text { canadense) } \\
\text { Cinema }\end{array}$ & $9,5(3 \%)$ & $272,6(97 \%)$ & $282,2(100 \%)$ \\
\hline $\begin{array}{c}\text { Televisão } \\
\text { pagante e } \\
\text { especializada }\end{array}$ & $11,9(21 \%)$ & $44,2(79 \%)$ & $56,1(100 \%)$ \\
\hline $\begin{array}{c}\text { Televisão } \\
\text { convencional }\end{array}$ & $87,0(24 \%)$ & $276,2(76 \%)$ & $363,1(100 \%)$ \\
\hline $\begin{array}{c}\text { Vídeo } \\
\text { doméstico } * *\end{array}$ & $3,3(3 \%)$ & $101,2(97 \%)$ & $104,5(100 \%)$ \\
\hline $\begin{array}{c}\text { Fora do } \\
\text { comércio }\end{array}$ & $3,6(23 \%)$ & $12,1(77 \%)$ & $15,7(100 \%)$ \\
\hline Total parcial & $115,4(14 \%)$ & $706,3(86 \%)$ & $821,6(100 \%)$ \\
\hline $\begin{array}{c}\text { Distribuição } \\
\text { externa } \\
\text { (mercado }\end{array}$ & & & $1007,2(100 \%)$ \\
\hline $\begin{array}{c}\text { estrangeiro) } \\
\text { Receitas de } \\
\text { clientes }\end{array}$ & $147,4(80 \%)$ & $38,1(21 \%)$ & $185,5(100 \%)$ \\
\hline $\begin{array}{c}\text { estrangeiros } \\
\text { TOTAL }\end{array}$ & $262,8(26 \%)$ & $744,4(74 \%)$ & 1000 \\
\hline
\end{tabular}

* Estão excluídas, as receitas ligadas à distribuição, em grande quantidade, de fitas de vídeo, bem como as da categoria “outras receitas”.

** Trata-se aqui do aluguel ou a venda de discos ou fitas de vídeo para a apresentação de filmes e de vídeos por um leitor de discos ou de fitas destinados a uma utilização doméstica. São excluídas desta categoria as receitas ligadas à distribuição, em grande quantidade, das empresas de venda e locação.

Fonte: Estatística Canadá. Le film et la vidéo, no 87F0010XPF, no catálogo, Ottawa, dezembro 2000 
Artigo recebido em julho de 2006

Aceito para publicação em agosto de 2006

\section{Referências}

BERNIER, Ivan et LAMOUREUX, Jean-François. Les politiques culturelles du Canada et du Québec, l'Organisation mondiale du commerce (OMC) et l'Accord de libre-échange nord américain (ALENA), dans Les politiques culturelles à l'épreuve - La culture entre l'État et le marché, sous la direction de Florian Sauvageau. Québec, Institut québécois de recherche sur la culture. 1996

BERNIER, Ivan. Cultural Goods and Services in International Trade Law. Dans The Culture/Trade Quandary - Canada's Policy Options, Dennis Browne éd., Centre for Trade Policy and Law. Ottawa: 1998

BERNIER, Ivan. Catalogue des instruments internationaux relatifs à la culture, 2 000: disponible sur le site http://www.mcc. gouv.qc.ca/international/diversiteculturelle/index.htmJACKSON, John H. World Trade and the Law of GATT. Indianapolis, Kansas City, New York: The Bobbs Merrill Co. Inc., 1969.

OMC, Doc. WT/DS31/AB/R. Disponivel no site: http://www.wto.org/

PAAPE, S. Treatment of Culture in Trade and Economic Agreements. Monographie, avril 2000 ;

RABOY, Marc, Ivan BERNIER, Florian SAUVAGEAU et Dave ATKINSON.

Desenvolvimento cultural e mundialização da economia. Québec: Instituto quebequiano de pesquisa sobre a cultura, 1994.

SAUVÉ, Pierre. Le traitement des produits et services culturels dans les accords commerciaux. Agence de la Francophonie, 2000

Estudo de François RODA. O apoio às indústrias culturais na área de língua francesa:" modalidades, desafios e incidências. Agência Francophonie:

http://confculture.francophonie.org/DocComplement/Rouet.cfm?id_groupe=2\&id_rubri que $=15$

RUIZ FABRI, Hélène. Chronique du règlement des différends de l'O.M.C. J.D.I., 1999/2, 


\section{Resumo}

O presente texto analisa juridicamente a Convenção da Unesco sobre Diversidade Cultural. Busca-se entender o processo de construção de um novo modelo protetivo e a sua integração com os direitos nacionais. Traz também reflexões sobre a interferência de normas exteriores à Organização Mundial do Comércio e ao seu ordenamento jurídico, o que se apresenta importante, sobretudo, em função dos desníveis de cogência entre as diferentes normas.

Palavras-chave: Diversidade cultural. Convenção da Unesco. Integração.

\begin{abstract}
This article analyses the UNESCO Convention on Cultural Diversity under a legal perspective. It attempts to understand the formation process of a new protective model as well as its integration with national rights. Also, it addresses the interferences of external norms regarding the World Trade Organization and its legal system, which is important especially because of the differences in cogency among different norms.
\end{abstract}

Keywords : Cultural diversity. Unesco Convention. Integration. 